\title{
Water-Quality and Bottom-Sediment- Chemistry Data for Left Hand Valley Reservoir, Boulder County, Colorado, January-August 1998
}

By Robert A. Kimbrough

U.S. GEOLOGICAL SURVEY

Open-File Report 99-192

Prepared in cooperation with the LEFT HAND WATER DISTRICT 


\title{
U.S. DEPARTMENT OF THE INTERIOR BRUCE BABBITT, Secretary
}

\author{
U.S. GEOLOGICAL SURVEY \\ Charles G. Groat, Director
}

The use of firm, trade, and brand names in this report is for identification purposes only and does not constitute endorsement by the U.S. Geological Survey.

For additional information write to:

District Chief

U.S. Geological Survey

Box 25046, Mail Stop 415

Denver Federal Center

Denver, CO 80225-0046
Copies of this report can be purchased from:
U.S. Geological Survey
Information Services
Box 25286
Federal Center
Denver, CO 80225 


\section{CONTENTS}

Abstract ...

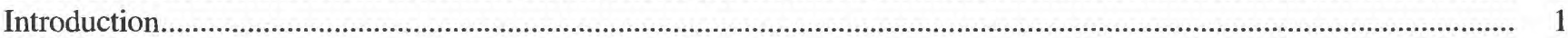

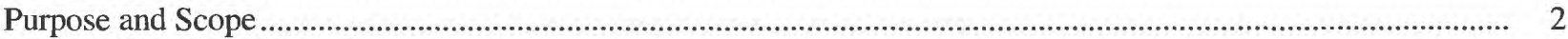

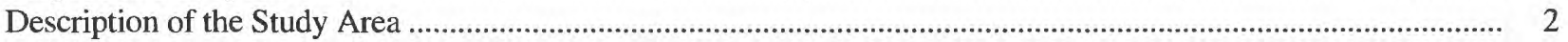

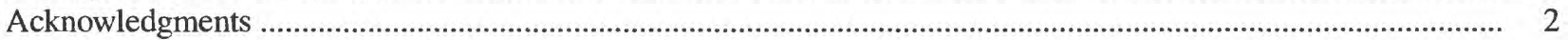

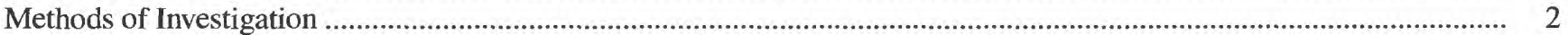

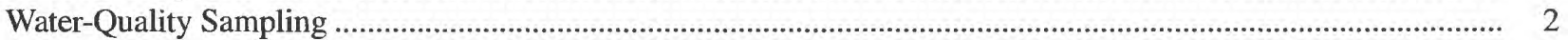

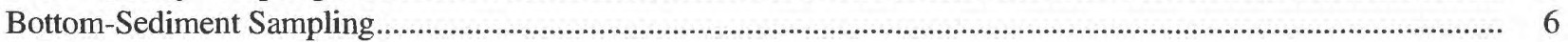

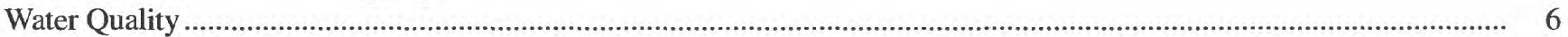

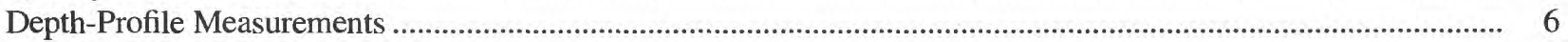

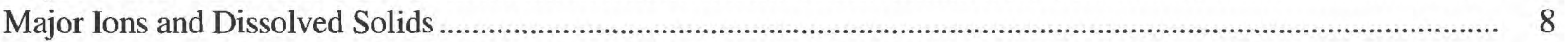

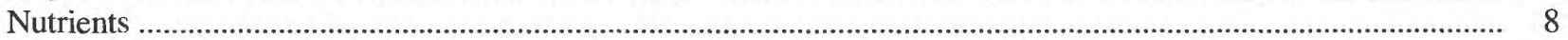

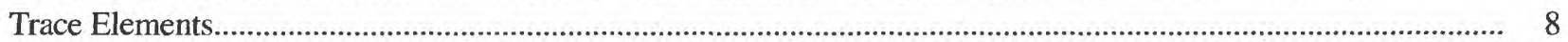

Volatile Organic Compounds and n-Nitrosodimethylamine .......................................................................... 11

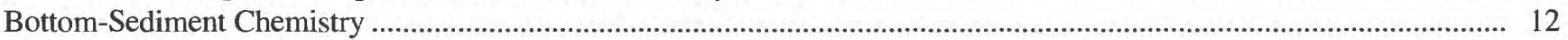

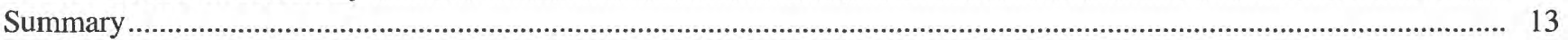

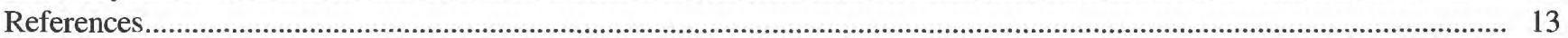

Water-Quality and Bottom-Sediment-Chemistry Data ............................................................................................ 15

\section{FIGURES}

1-2. Maps showing:

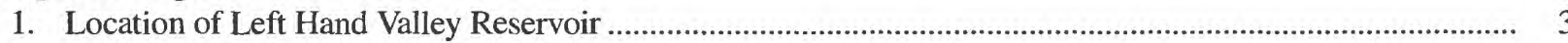

2. Location of inflow/outflow ditches and reservoir monitoring sites................................................................. 4

3-4. Graphs showing:

3. Profiles of water temperature, dissolved oxygen, $\mathrm{pH}$, and specific conductance at sites R1 and R2,

Left Hand Valley Reservoir, January-August 1998

4. Concentrations of dissolved manganese and dissolved oxygen in bottom-water samples from

Left Hand Valley Reservoir, January-August 1998

\section{TABLES}

1. Description of monitoring sites and water-quality samples collected in Left Hand Valley Reservoir, January-August 1998

(1)




\section{CONVERSION FACTORS, DEFINITIONS, AND ABBREVIATIONS}

\begin{tabular}{rrl}
\hline Multiply & By & To obtain \\
\hline acre & 0.004047 & square kilometer \\
acre-foot (acre-ft) & 1,233 & cubic meter \\
foot (ft) & 0.3048 & meter \\
gallon (gal) & 3.785 & liter $(\mathrm{L})$ \\
inch & 2.54 & centimeter $(\mathrm{cm})$ \\
mile & 1.609 & kilometer $(\mathrm{km})$ \\
pound $(\mathrm{lb})$ & 0.4536 & kilogram $(\mathrm{kg})$ \\
\hline
\end{tabular}

Temperature in degrees Celsius $\left({ }^{\circ} \mathrm{C}\right)$ may be converted to degrees Fahrenheit $\left({ }^{\circ} \mathrm{F}\right)$ as follows:

$\mathrm{F}=1.8 \mathrm{C}+32$

Specific conductance is given in microsiemens per centimeter at 25 degrees Celsius $\left(\mu \mathrm{S} / \mathrm{cm}\right.$ at $\left.25^{\circ} \mathrm{C}\right)$.

Concentrations of chemical constituents in water are given either in milligrams per liter $(\mathrm{mg} / \mathrm{L})$ or micrograms per liter $(\mu \mathrm{g} / \mathrm{L})$.

\section{ADDITIONAL ABBREVIATIONS}

$\mu \mathrm{g} / \mathrm{g} \quad$ micrograms per gram

$\mu \mathrm{g} / \mathrm{L} \quad$ micrograms per liter

$\mu \mathrm{m} \quad$ micrometer

$\mu \mathrm{S} / \mathrm{cm} \quad$ microsiemens per centimeter at 25 degrees Celsius

$\mathrm{mg} / \mathrm{L} \quad$ milligrams per liter 


\title{
Water-Quality and Bottom-Sediment-Chemistry Data for Left Hand Valley Reservoir, Boulder County, Colorado, January-August 1998
}

\author{
By Robert A. Kimbrough
}

Abstract

From January through August 1998, waterquality and bottom-sediment-chemistry data were collected for Left Hand Valley Reservoir, a small reservoir (capacity 1,600 acre-feet) located about 5 miles north of Boulder, Colorado. Water temperature, dissolved oxygen, and $\mathrm{pH}$ were uniform throughout the reservoir water column in winter (January and March) but decreased with depth during spring and summer. In July and August, dissolved oxygen concentrations decreased to less than 1 milligram per liter in some of the deepest areas of the reservoir. Throughout the study, dissolved-solids concentrations were relatively uniform with depth, as indicated by measurements of specific conductance. Nitrogen in the water column predominantly was in the organic phase, and concentrations of total organic plus ammonia nitrogen ranged from 0.1 to 0.3 milligram per liter. Median concentrations of dissolved inorganic nitrogen (ammonia and nitrite plus nitrate nitrogen) were less than 0.02 milligram per liter. Total phosphorus concentrations ranged from less than 0.01 to 0.059 milligram per liter. Dissolved orthophosphorus concentrations almost always were less than the detection limit of 0.001 milligram per liter. With the exception of manganese concentrations, maximum dissolved concentrations of ten detected trace elements ranged from 1 to 46 micrograms per liter. Dissolved manganese concentrations in bottomwater samples varied between 2 and 478 micrograms per liter and increased with decreasing dissolved oxygen. Volatile organic compounds and n-nitrosodimethylamine, a metabolite of the rocket fuel component 1,1-dimethylhydrazine, were not detected in any of four water samples collected in January and July. Trace-element concentrations in reservoir bottom sediments were comparable to background concentrations determined from reservoir and streambed sediments in the South Platte River Basin.

\section{INTRODUCTION}

Left Hand Valley Reservoir was constructed in the early 1950's by the Left Hand Ditch Company to provide irrigation water to farms located northeast of Boulder, Colorado. Currently (1999), the reservoir is used for irrigation, recreation, and as a source of drinking water for the Left Hand Water District (LHWD). The LHWD uses reservoir water primarily during summer to supply drinking water to several small communities north of Boulder; however, the district is considering using the reservoir as a yearround source of drinking water.

Prior to this study, minimal information on the water quality of Left Hand Valley Reservoir existed. In recent years, the reservoir had been sampled twice for organic solvents and rocket fuel components, which may be contained in a plume of ground water and seeps located to the west and upgradient from the reservoir. The contaminated ground-water plume may emanate from a former aircraft facility located about 1 mile west of the reservoir. In December 1994, relatively low levels of bromoform, vinyl chloride, and the rocket fuel hydrazine were detected in Left Hand Valley Reservoir. None of these compounds were detected in a subsequent sample collected in March 1996. 
Concerns about the lack of water-quality information and of the potential to increase reservoir withdrawals for drinking water prompted the LHWD to acquire additional water-quality data for the reservoir. In 1998, the U.S. Geological Survey (USGS), in cooperation with the LHWD, conducted a study to determine the physical and chemical characteristics of water in Left Hand Valley Reservoir and to determine if organic compounds such as bromoform, vinyl chloride, and rocket fuel metabolites were present in the reservoir water column.

\section{Purpose and Scope}

This report presents water-quality and bottomsediment-chemistry data for Left Hand Valley Reservoir. At two sites and on seven occasions between January and August 1998, depth-profile measurements were obtained for water temperature, dissolved oxygen, $\mathrm{pH}$, and specific conductance; also, waterquality samples were collected for analysis of major ions, alkalinity, dissolved solids, nutrients (nitrogen and phosphorus), trace elements, organic carbon, fecal coliform bacteria, and chlorophyll. Water-quality samples collected from two other sites in January and July 1998 were analyzed for volatile organic compounds (VOCs) and n-nitrosodimethylamine (NDMA), a metabolite of the rocket fuel component 1,1-dimethylhydrazine. In July 1998, a single sample of reservoir bottom sediment was collected for analysis of selected trace elements and several additional constituents. Sampling originally planned for September 1998-February 1999 was canceled after the reservoir was drained for repairs in late August 1998.

\section{Description of the Study Area}

Left Hand Valley Reservoir is situated in the Saint Vrain Creek Basin of the South Platte River Basin and is located about 5 miles north of Boulder, Colorado (fig. 1). The reservoir was created by the construction of earthen dams on Dry Creek and one of its unnamed tributaries. The bedrock underlying the reservoir is the Pierre Shale of Late Cretaceous age (Trimble, 1975). The reservoir is primarily filled with water diverted from Left Hand Creek through the Crocker and Left Hand Filler Ditches (fig. 2). Inflow from natural sources and the Haldi Ditch (fig. 2) are minimal. Water is released from the reservoir back to Left Hand Creek and to various irrigation ditches through the Left Hand Valley Outlet Ditch (fig. 2). When filled to capacity, Left Hand Valley Reservoir contains about 1,600 acre-ft of water and the surface area is about 110 acres. The mean depth is about $14.5 \mathrm{ft}$, and maximum depth is about $35 \mathrm{ft}$. During the study, reservoir storage was filled to capacity (1,600 acre-ft) from January through June. Storage was less in July and August when the reservoir was being drained for dam repairs (end-of-month storage for July and August was 1,300 and 0 acre-ft, respectively).

\section{Acknowledgments}

The author would like to thank Kathy Peterson, of the Left Hand Water District, for providing information and data on the reservoir, and USGS employees Dennis Smits and Janet Heiny for their assistance with sample collection and processing onsite.

\section{METHODS OF INVESTIGATION}

\section{Water-Quality Sampling}

Physical properties were measured, and water samples were collected for analysis of chemical constituents at four sites in Left Hand Valley Reservoir (sites R1-R4, fig. 2). Most of the data collection occurred at two deep sites (R1 and R2). Sampling at two shallow sites (R3 and R4) was limited to the collection of water for analysis of VOCs and NDMA. The shallow sites were located near the sites where VOC and NDMA sampling had been conducted in March 1996 (Kathy Peterson, Left Hand Water District, written commun., 1997). A description of the reservoir monitoring sites and a summary of the waterquality samples collected at each site are presented in table 1 .

To minimize the potential of sample contamination from metallic surfaces and to minimize losses through adsorption, sample-collection and sampleprocessing equipment made from acrylic, polyethylene, or Teflon was used. Sampling equipment was 


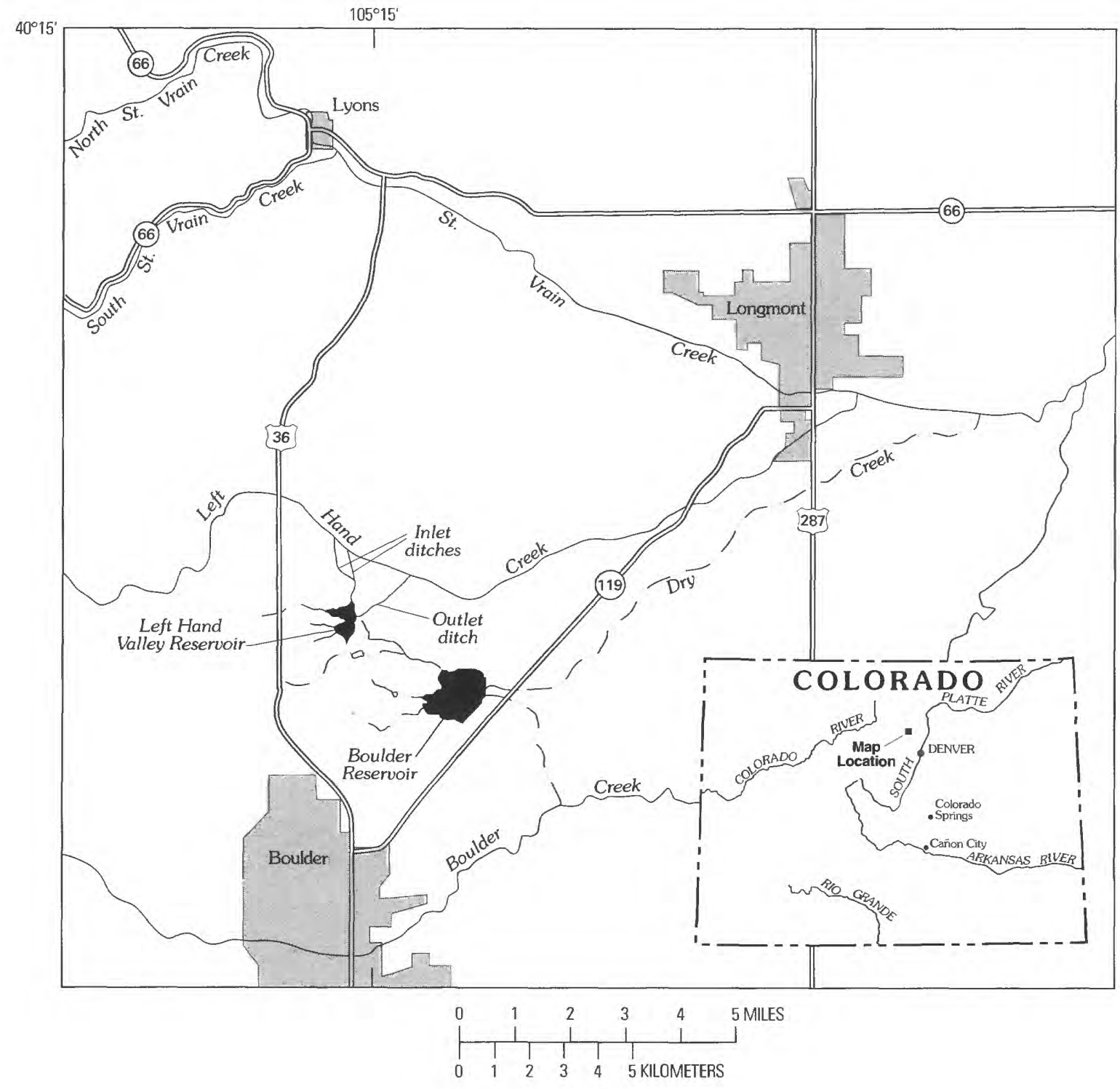

Figure 1. Location of Left Hand Valley Reservoir. 


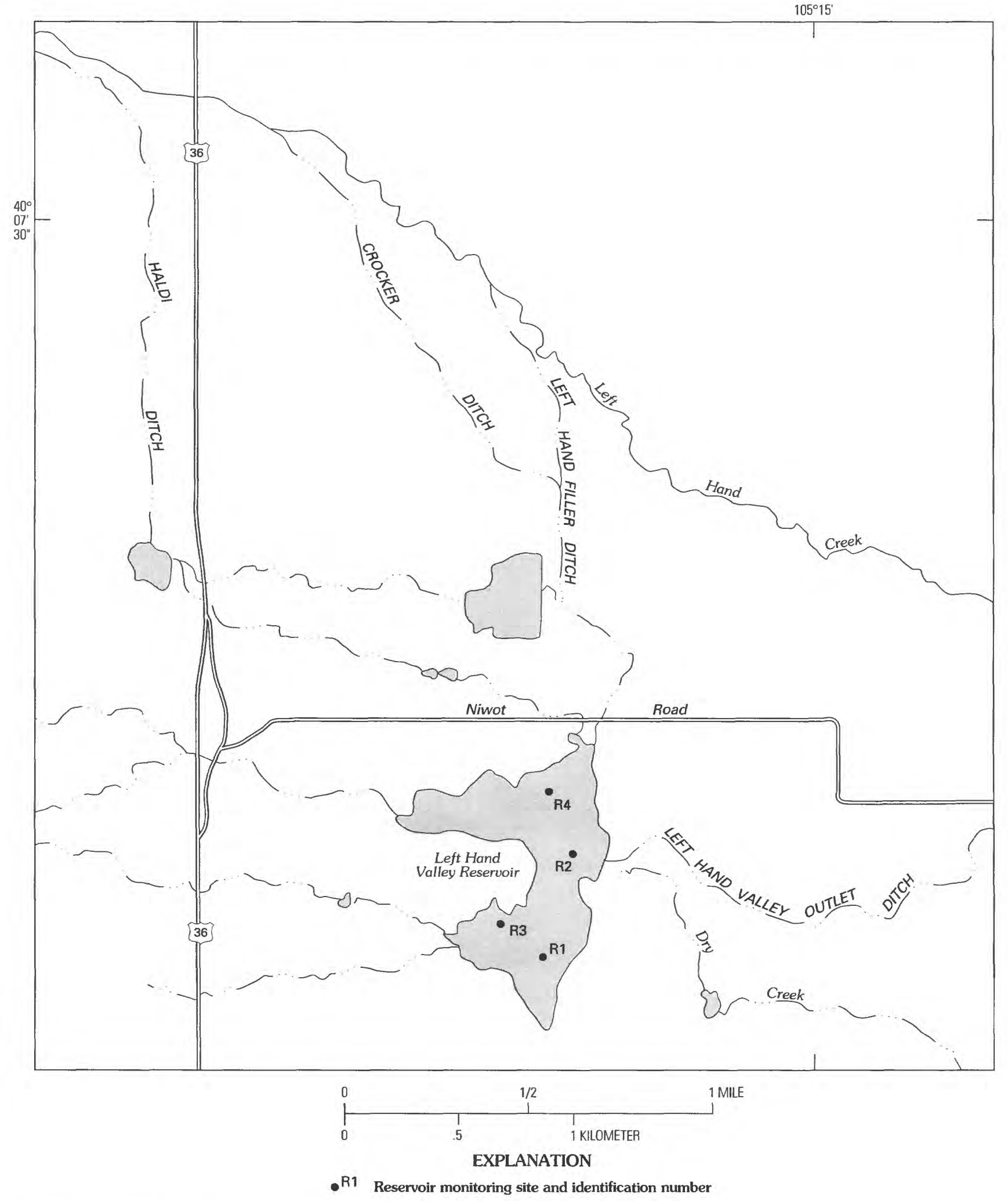

Figure 2. Location of inflow/outflow ditches and reservoir monitoring sites. 
Table 1. Description of monitoring sites and water-quality samples collected in Left Hand Valley Reservoir, JanuaryAugust 1998

[USGS, U.S. Geological Survey; maximum depth, maximum depth recorded during this study; major constituents are major ions, alkalinity, and dissolved solids; nutrients are nitrogen and phosphorus; NDMA, n-nitrosodimethylamine; Photic, composite sample collected from the reservoir photic zone; Bottom, discrete sample collected near the reservoir bottom; --, not collected]

\begin{tabular}{|c|c|c|c|c|c|c|}
\hline \multirow[b]{2}{*}{$\begin{array}{c}\text { Site } \\
\text { number } \\
\text { (figure 1) }\end{array}$} & \multirow[b]{2}{*}{$\begin{array}{l}\text { USGS site } \\
\text { identification } \\
\text { number }\end{array}$} & \multirow[b]{2}{*}{ Site name } & \multirow[b]{2}{*}{$\begin{array}{l}\text { Maxi- } \\
\text { mum } \\
\text { depth, } \\
\text { in feet }\end{array}$} & \multicolumn{3}{|c|}{ Samples collected } \\
\hline & & & & $\begin{array}{c}\text { Major } \\
\text { constituents, } \\
\text { nutrients, } \\
\text { organic } \\
\text { carbon, } \\
\text { trace } \\
\text { elements }\end{array}$ & $\begin{array}{l}\text { Chlorophyll } \\
a \text { and } b \text {, } \\
\text { fecal } \\
\text { coliform } \\
\text { bacteria }\end{array}$ & $\begin{array}{l}\text { Volatile } \\
\text { organic } \\
\text { compounds, } \\
\text { NDMA }\end{array}$ \\
\hline R1 & 400546105154900 & $\begin{array}{l}\text { Left Hand Valley Reservoir } \\
\text { near south dam }\end{array}$ & 35.1 & $\begin{array}{l}\text { Photic, } \\
\text { Bottom }\end{array}$ & Photic & -- \\
\hline $\mathrm{R} 2$ & 400600105154400 & $\begin{array}{l}\text { Left Hand Valley Reservoir } \\
\text { near north dam }\end{array}$ & 33.9 & $\begin{array}{l}\text { Photic, } \\
\text { Bottom }\end{array}$ & Photic & -- \\
\hline R3 & 400551105155700 & $\begin{array}{l}\text { Left Hand Valley Reservoir } \\
\text { near southwest inlet }\end{array}$ & 5.0 & - & -- & Bottom \\
\hline $\mathrm{R} 4$ & 400609105154800 & $\begin{array}{l}\text { Left Hand Valley Reservoir } \\
\text { near northeast inlet }\end{array}$ & 12.2 & - & -- & Bottom \\
\hline
\end{tabular}

cleaned prior to use with a nonphosphate laboratory detergent and rinsed first with tap water, then with a 5-percent solution of hydrochloric acid, and last with deionized water. The equipment was rinsed with copious amounts of native water at the sampling sites before sample collection. Glass sample containers used for organic carbon, VOC, and NDMA analyses were cleaned by baking at $450^{\circ} \mathrm{C}$ for 8 hours and were not field rinsed. Water for fecal coliform analysis was collected in sterilized, polyethylene containers that were not field rinsed.

Prior to sample collection at the deep sites, water transparency was measured with a Secchi disc, and depth-profile measurements of water temperature, $\mathrm{pH}$, dissolved oxygen, and specific conductance were obtained with a multiparameter meter. A portable computer was used to record depth-profile measurements taken at approximately $1-\mathrm{ft}$ intervals.

Two water samples were collected at each of the two deep monitoring sites. The first sample was a depth-integrated sample collected from the photic zone (defined as twice the Secchi-disc depth) and the second sample was collected at a single depth about 2-3 ft above the reservoir bottom. Water samples were collected from discrete depths by using a horizontally suspended, 4-L, acrylic Van Dorn sampler. Samples of water from the photic zones were collected at the water surface, and then at about every $2 \mathrm{ft}$, and were composited in a 14-L polyethylene churn splitter.

Samples for VOC and NDMA analysis were collected from one depth at each of the two shallow sites. Using a peristaltic pump and low-density polyethylene tubing, aliquots of unfiltered water were collected in $40-\mathrm{mL}$ glass vials by pumping from a depth of about $1 \mathrm{ft}$ above the reservoir bottom. To reduce aeration of the sample, water was pumped at a low-flow rate and the vials were purged with water for at least one minute.

Samples collected from the two deep reservoir sites were prepared for analysis onsite by using methods described by Horowitz and others (1994), Shelton (1994), and Porter and others (1993). Aliquots of unfiltered water were collected for analysis of the total recoverable concentrations of the constituents listed in tables 8-10, at the back of this report. With the exception of organic carbon, sample water filtered through a $0.45-\mu \mathrm{m}$ cellulose nitrate filter was used to determine constituent concentrations in the dissolved phase (herein defined as the dissolved phase).

Dissolved organic carbon concentrations were determined from water passed through a $0.45-\mu \mathrm{m}$ silver filter. Chlorophyll concentrations were determined from suspended material retained on a $0.7-\mu \mathrm{m}$ glassfiber filter. Samples for trace-element analyses were 
acidified to a $\mathrm{pH}$ of less than 2 by using ultrapure nitric acid; VOC samples were acidified with 1:1 hydrochloric acid. Samples for fecal coliform, nutrient, chlorophyll, organic carbon, VOC, and NDMA analyses were immediately chilled to $4^{\circ} \mathrm{C}$ in the field.

Fecal coliform analyses were conducted by the Boulder County Health Department using the Most Probable Number method (Jodi Hogan, Boulder County Health Department, written commun., 1998). The remaining analyses were conducted at the USGS National Water-Quality Laboratory in Arvada, Colorado, using methods described by Fishman and Friedman (1989), Patton and Truitt (1992), Faires (1993), Fishman (1993), and Rose and Schroeder (1995). About 15 percent of the total number of samples were for quality control. These included field equipment blanks, prepared with inorganic- or organic-free water, and split-replicate samples.

\section{Bottom-Sediment Sampling}

Concentrations of 47 constituents in reservoir bottom sediments were determined as part of this study. In July 1998, a sample of bottom sediment was collected at site $\mathrm{R} 2$ by lowering a stainless steel Eckman dredge over the side of a boat. Using a Teflon spoon, a subsample was collected from the upper $2-3 \mathrm{~cm}$ of sediment that was captured in the dredge. The subsample was collected from the center of the sampler, away from the metallic sidewalls. On shore, the sample was sieved in a mobile laboratory and the fraction measuring less than $63 \mu \mathrm{m}$ was retained and stored at $4{ }^{\circ} \mathrm{C}$ for analysis. Constituent concentrations in reservoir-bottom sediments were determined by the U.S. Geological Survey Chemistry Services Group in Denver by using total digestion procedures described by Arbogast (1990).

\section{WATER QUALITY}

\section{Depth-Profile Measurements}

The general water-quality properties measured in the field for this study were water temperature, dissolved oxygen, $\mathrm{pH}$, and specific conductance. Depth-profile measurements of the four properties, obtained at sites R1 and R2, are plotted in figure 3 and listed in tables 6 and 7, at the back of this report.

In January and March 1998, water temperature was about $4{ }^{\circ} \mathrm{C}$ throughout the reservoir water column (fig. 3). After March, water temperature decreased with depth, primarily because of variations in water density caused by solar heating at the reservoir surface. By July, water temperature varied by about $10^{\circ} \mathrm{C}$ throughout the water column, and maximum temperatures at the water surface were about $25^{\circ} \mathrm{C}$. During the study, no temperatures exceeded $30^{\circ} \mathrm{C}$, the water-quality standard for Left Hand Valley Reservoir set by the Colorado Department of Public Health and Environment (CDPHE) (1996).

Profiles of dissolved oxygen were similar to profiles of water temperature (fig. 3). Dissolved oxygen levels were uniformly around $10 \mathrm{mg} / \mathrm{L}$ through March; but by May, dissolved oxygen began to decrease with depth, and during late July and August, anoxic (zero oxygen) conditions were measured near the bottom of the reservoir. The dissolved oxygen standard for Left Hand Valley Reservoir is $5 \mathrm{mg} / \mathrm{L}$; however, in Colorado lakes and reservoirs, dissolved oxygen standards are intended only for the upper and middle strata of the water column (epilimnion and metalimnion) and the lower strata (hypolimnion) are exempt from the standard (Colorado Department of Public Health and Environment, 1996).

Throughout the water column, $\mathrm{pH}$, a measure of the hydrogen-ion activity, ranged from 6.5 to 8.4 and no values were outside the range of 6.5 to 9.0 , the water-quality standard set by the CDPHE (1996). During January and March 1998, pH was fairly uniform throughout the water column (fig. 3). After March, $\mathrm{pH}$ steadily decreased with depth and the lowest values were recorded near the bottom of the reservoir in July and August.

Specific conductance is an indirect measure of the dissolved-solids concentration. For this study, the conversion factor between specific conductance and dissolved-solids concentration ranged from 0.57 to 0.66 and averaged 0.62 . On most sampling dates, variations of specific conductance were small throughout the reservoir water column (fig. 3), indicating that the concentration of dissolved solids was uniformly distributed with depth. On a temporal basis, specific conductance was higher from January through May (213-297 $\mu \mathrm{S} / \mathrm{cm}$ ) as compared to July and August (80-139 $\mu \mathrm{S} / \mathrm{cm})$. 


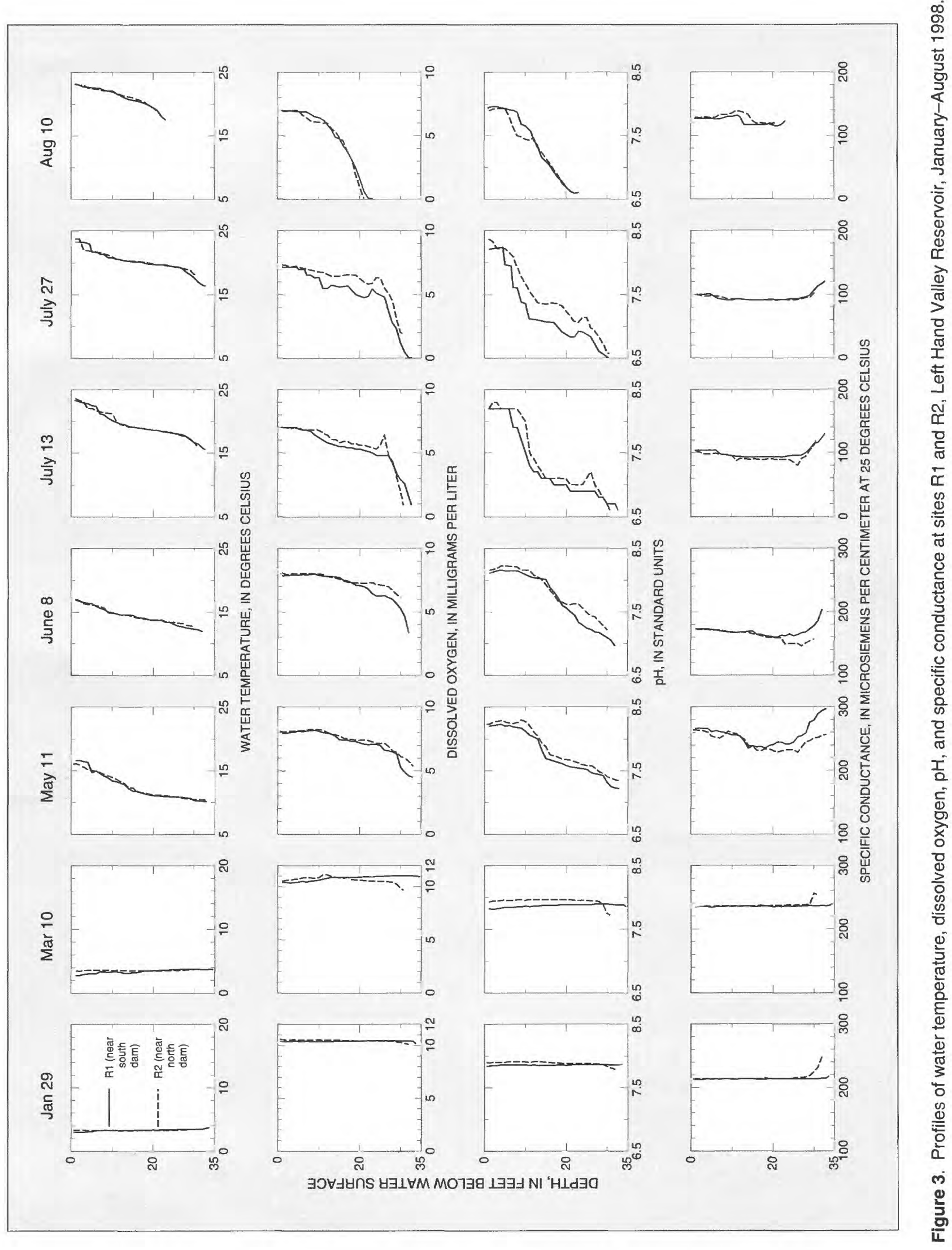




\section{Major lons and Dissolved Solids}

The major ions analyzed for this study (calcium, chloride, fluoride, magnesium, potassium, sodium, sulfate, and silica) are constituents commonly dissolved in most natural waters. Concentrations of an additional major ion-bicarbonate - may be determined from measurements of alkalinity. Summary statistics for major-ion and alkalinity concentrations in Left Hand Valley Reservoir are listed in table 2. The CDPHE has not set standards for major-ion concentrations in the reservoir. Standards for a few constituents that have been determined by the CDPHE (1996) for upper Left Hand Creek or by the U.S. Environmental Protection Agency (USEPA) (1996) for treated drinking water are listed in table 2 as a point of reference for the concentrations measured in this study.

The sum of dissolved solids, reported in milligrams per liter, is a direct measurement of the total dissolved-constituent concentration. Major ions make up the bulk of dissolved-solids concentrations; other constituents such as nitrogen, phosphorus, organic carbon, and the trace elements listed in table 3 account for the remainder. The CDPHE has not set standards for dissolved solids in State waters; however, there is a USEPA-recommended limit for treated drinking water of $500 \mathrm{mg} / \mathrm{L}$ (U.S. Environmental Protection Agency, 1996). Additionally, crop losses might occur when dissolved-solids concentrations reach about $700-850 \mathrm{mg} / \mathrm{L}$ in irrigation water (U.S. Department of the Interior, 1994). Dissolved-solids concentrations in Left Hand Valley Reservoir ranged from 58 to $174 \mathrm{mg} / \mathrm{L}$ (table 2 ) and no values exceeded the standards cited here.

\section{Nutrients}

Nitrogen and phosphorus concentrations in Left Hand Valley Reservoir were small. In fact, after March 1998 , the laboratory analytical methods for determining nitrogen and phosphorus concentrations were changed to allow for lower detection limits ( 8 samples were analyzed by using higher detection limits, 20 samples were analyzed by using lower detection limits).

Nitrogen in Left Hand Valley Reservoir predominantly was in the organic phase, either as dissolved or suspended organic nitrogen. Concentrations of total organic plus ammonia nitrogen ranged from 0.1 to $0.3 \mathrm{mg} / \mathrm{L}$ (table 2). Concentrations of dissolved inorganic nitrogen, measured as ammonia, and nitrite plus nitrate were about one order of magnitude lower than organic concentrations. Median concentrations were less than $0.02 \mathrm{mg} / \mathrm{L}$ for ammonia and $0.016 \mathrm{mg} / \mathrm{L}$ for nitrite plus nitrate nitrogen (table 2). The CDPHE (1996) has set a standard for un-ionized ammonia that is applicable to Left Hand Valley Reservoir. Unionized ammonia concentrations are calculated using ammonia concentrations, $\mathrm{pH}$, and water temperature. All un-ionized ammonia concentrations were at least 2 orders of magnitude lower than the standard of $0.1 \mathrm{mg} / \mathrm{L}$ (table 2). Total phosphorus concentrations ranged from less than 0.01 to $0.059 \mathrm{mg} / \mathrm{L}$ (table 2). Concentrations of dissolved orthophosphorus, the form of inorganic phosphorus most readily available for algal growth, almost always were less than the detection limit of $0.001 \mathrm{mg} / \mathrm{L}$. Nitrogen and phosphorus levels were less than standards or guidelines that have been established by the CDPHE (1996) and by the USEPA (1986) (table 2).

\section{Trace Elements}

The term "trace elements" commonly refers to substances that almost always occur in concentrations less than $1.0 \mathrm{mg} / \mathrm{L}$ in natural waters. Eight of the 18 trace elements analyzed for this study were not detected in any samples (table 3). Most dissolved concentrations of the 10 detected trace elements were less than $10 \mu \mathrm{g} / \mathrm{L}$ and no concentrations exceeded any standards or guidelines that have been established for water in Left Hand Valley Reservoir or treated drinking water. Aluminum, barium, iron, and manganese were measured at dissolved concentrations greater than or equal to $20 \mu \mathrm{g} / \mathrm{L}$. All four of these elements are fairly abundant in igneous and sedimentary rocks, and both rock types are common in the drainage basin upstream from and surrounding Left Hand Valley Reservoir.

Of all the trace elements, the concentrations of dissolved manganese were the most variable throughout the study (table 3). Dissolved manganese concentrations generally were small in samples collected from the photic zone, but in samples of bottom water, manganese concentrations ranged from 2 to $478 \mu \mathrm{g} / \mathrm{L}$ (table 9 , at the back of this report). 
Graphs of dissolved manganese and dissolved oxygen concentrations in bottom-water samples indicate that manganese concentrations increased with decreasing dissolved oxygen (fig. 4). Manganese concentrations greater than $100 \mu \mathrm{g} / \mathrm{L}$ generally were detected when dissolved oxygen levels were less than $2 \mathrm{mg} / \mathrm{L}$ at depths of 2 to $3 \mathrm{ft}$ off the reservoir bottom (the depths at which bottom-water samples were collected).

Table 2. Summary of water-quality data for major ions, alkalinity, dissolved solids, and nutrients, Left Hand Valley Reservoir, January-August 1998

[Concentrations are reported as dissolved unless noted otherwise; --, no data; nitrogen species as nitrogen; orthophosphorus as phosphorus; $<$, less than]

\begin{tabular}{|c|c|c|c|c|c|}
\hline \multirow[b]{2}{*}{ Constituent } & \multirow[b]{2}{*}{$\begin{array}{l}\text { Number of } \\
\text { detections in } \\
28 \text { samples }\end{array}$} & \multicolumn{4}{|c|}{ Concentration, in milligrams per liter } \\
\hline & & Minimum & Maximum & Median & $\begin{array}{c}\text { Standard } \\
\text { or } \\
\text { guideline }\end{array}$ \\
\hline \multicolumn{6}{|c|}{ Major ions, alkalinity, and dissolved solids } \\
\hline Alkalinity & 28 & 28 & 68 & 42 & -- \\
\hline Calcium & 28 & 10 & 30 & 18 & -- \\
\hline Chloride & 28 & 1.6 & 6.0 & 2.8 & ${ }^{1} 250$ \\
\hline Dissolved solids & 28 & 58 & 174 & 114 & ${ }^{2} 500$ \\
\hline Fluoride & 28 & 0.3 & 0.9 & 0.5 & 22 \\
\hline Magnesium & 28 & 2.7 & 8.9 & 5.4 & -- \\
\hline Potassium & 28 & 0.5 & 1.1 & 0.8 & -- \\
\hline Silica & 28 & 5.3 & 10 & 5.8 & -- \\
\hline Sodium & 28 & 2.8 & 9.3 & 5.8 & -- \\
\hline Sulfate & 28 & 12 & 62 & 34 & ${ }^{1} 250$ \\
\hline \multicolumn{6}{|c|}{ Nutrients } \\
\hline Total organic nitrogen plus ammonia & 28 & 0.1 & 0.3 & 0.2 & -- \\
\hline Ammonia & 22 & $<0.002$ & 0.057 & $<0.02$ & -- \\
\hline Nitrite plus nitrate & 12 & $<0.005$ & 0.14 & 0.016 & $\begin{array}{l}{ }^{3} 0.5 \text { (nitrite) } \\
{ }^{1} 10 \text { (nitrate) }\end{array}$ \\
\hline Un-ionized ammonia ${ }^{4}$ & 22 & \multicolumn{3}{|c|}{----all values less than 0.001 ---- } & ${ }^{3} 0.1$ \\
\hline Total phosphorus & 22 & $<0.01$ & 0.059 & 0.02 & ${ }^{5} 0.1$ \\
\hline Orthophosphorus & 9 & $<0.001$ & 0.02 & $<0.001$ & ${ }^{6} 0.05$ \\
\hline
\end{tabular}

\footnotetext{
${ }^{1}$ Water-quality standard for segment 4 of the Saint Vrain Creek Basin [Left Hand Creek upstream from U.S. Highway 36 (fig. 2)] (Colorado Department of Public Health and Environment, 1996).

${ }^{2}$ Secondary maximum contaminant level for drinking water (U.S. Environmental Protection Agency, 1996).

${ }^{3}$ Water-quality standard for segment 5 of the Saint Vrain Creek Basin (includes Left Hand Valley Reservoir) (Colorado Department of Public Health and Environment, 1996).

${ }^{4}$ Calculated using dissolved ammonia, $\mathrm{pH}$, and water temperature.

${ }^{5}$ Recommended limit for controlling eutrophication in rivers (U.S. Environmental Protection Agency, 1986).

${ }^{6}$ Recommended limit for orthophosphate where rivers enter lakes and reservoirs (U.S. Environmental Protection Agency, 1986).
} 
Table 3. Summary of water-quality data for trace elements, Left Hand Valley Reservoir, January-August 1998

[Concentrations are reported as dissolved unless noted otherwise; <, less than; --, not computed or no standard or guideline]

\begin{tabular}{|c|c|c|c|c|c|}
\hline \multirow[b]{2}{*}{ Trace element } & \multirow{2}{*}{$\begin{array}{l}\text { Number of } \\
\text { detections in } \\
28 \text { samples }\end{array}$} & \multicolumn{4}{|c|}{ Concentration, in micrograms per liter } \\
\hline & & Minimum & Maximum & Median & Standard or guideline \\
\hline Aluminum & 22 & $<1$ & 40 & 10 & ${ }^{\mathrm{T}} 50-200$ \\
\hline Antimony & 0 & -- & $<1$ & -- & ${ }^{2} 6$ \\
\hline Arsenic & 6 & $<1$ & 2 & $<1$ & ${ }^{3} 100$ (total recoverable) \\
\hline Barium & 28 & 20 & 46 & 31 & ${ }^{2} 2,000$ \\
\hline Beryllium & 0 & -- & $<1$ & - & $2_{4}$ \\
\hline Cadmium & 0 & - & $<1$ & -- & ${ }^{4} 0.9$ \\
\hline Chromium & 8 & $<1$ & 1 & $<1$ & ${ }^{3} 11$ \\
\hline Cobalt & 0 & -- & $<1$ & -- & -- \\
\hline Copper & 27 & $<1$ & 3 & 2 & ${ }^{4} 8.9$ \\
\hline Iron & 12 & $<10$ & 20 & $<10$ & ${ }^{3} 1,000$ (total recoverable) \\
\hline Lead & 0 & -- & $<1$ & - & ${ }^{4} 2.4$ \\
\hline Manganese & 21 & $<1$ & 478 & 2 & ${ }^{3} 1,000$ (total recoverable) \\
\hline Molybdenum & 18 & $<1$ & 2 & 1 & - \\
\hline Nickel & 0 & -- & $<1$ & -- & ${ }^{4} 74$ \\
\hline Selenium & 0 & -- & $<1$ & - & ${ }^{3} 17$ \\
\hline Silver & 0 & -- & $<1$ & - & ${ }^{4} 0.18$ \\
\hline Uranium & 17 & $<1$ & 4 & 2 & ${ }^{2} 20$ (proposed) \\
\hline Zinc & 20 & $<1$ & 6 & 2 & ${ }^{4} 80$ \\
\hline
\end{tabular}

${ }^{1}$ Secondary maximum contaminant level for drinking water (U.S. Environmental Protection Agency, 1996).

${ }^{2}$ Maximum contaminant level for drinking water (U.S. Environmental Protection Agency, 1996).

${ }^{3}$ Water-quality standard for segment 5 of the Saint Vrain Creek Basin (includes Left Hand Valley Reservoir) (Colorado Department of Public Health and Environment, 1996).

${ }^{4}$ Water-quality standard for Left Hand Valley Reservoir calculated with the mean hardness concentration from this study and the Table Value Standard equations for segment 5 of the Saint Vrain Creek Basin (Colorado Department of Public Health and Environment, 1996). 


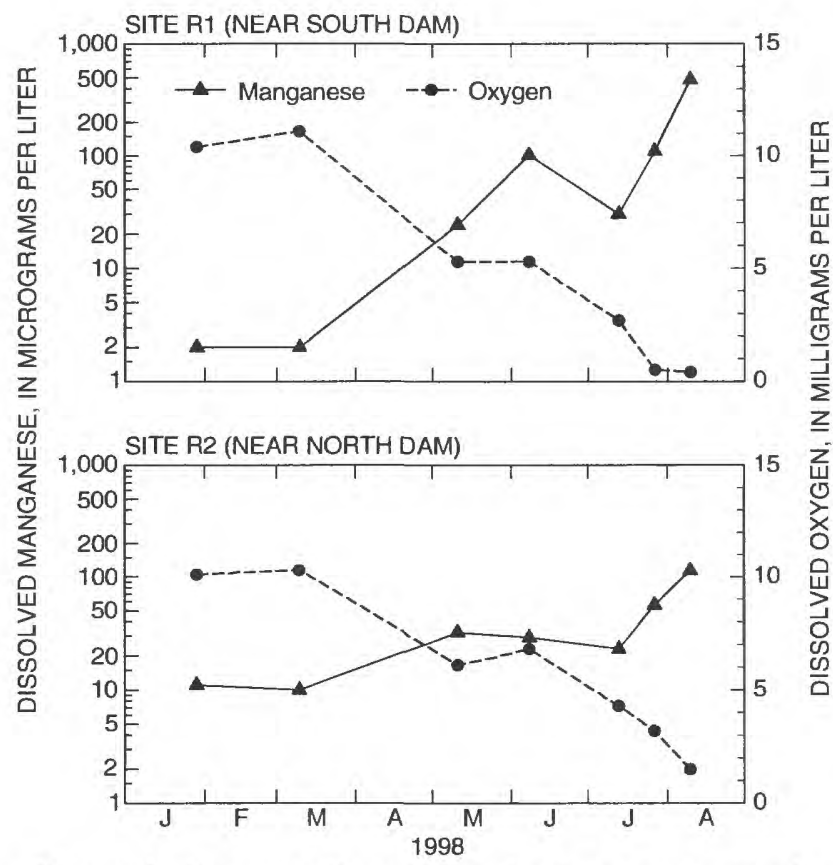

Figure 4. Concentrations of dissolved manganese and dissolved oxygen in bottom-water samples from Left Hand Valley Reservoir, January-August 1998.

\section{Volatile Organic Compounds and n-Nitrosodimethylamine}

Samples for analysis of VOCs and NDMA were collected in winter (January) and summer (July) at the two shallow sites, R3 and R4 (fig. 2). Neither the VOCs listed in table 4 nor NDMA was detected in any of the four samples (analytical results are listed in table 10, at the back of this report). Left Hand Valley Reservoir froze over almost completely in January 1998. The winter sampling was scheduled to occur as close to ice-off as possible to maximize the potential for detecting VOCs that were trapped below ice cover. The winter samples were collected on January 29, one day after a large ice cover had melted away from most of the reservoir surface (samples at R3 were collected at the edge of ice cover). Nonetheless, VOCs and NDMA were not detected in January or July.

Table 4. Volatile organic compounds analyzed for but not detected in four water samples collected from Left Hand Valley Reservoir, January and July 1998

[USGS, U.S. Geological Survey]

\begin{tabular}{clll}
\hline $\begin{array}{c}\text { USGS } \\
\text { parameter } \\
\text { code }\end{array}$ & \multicolumn{1}{c}{ Compound } & $\begin{array}{c}\text { USGS } \\
\text { parameter } \\
\text { code }\end{array}$ & \multicolumn{1}{c}{ Compound } \\
\hline 34496 & 1,1-Dichloroethane & 32106 & Chloroform \\
34501 & 1,1-Dichloroethylene & 34668 & Dichlorodifluoromethane \\
34536 & 1,2-Dichlorobenzene & 34371 & Ethylbenzene \\
32103 & 1,2-Dichloroethane & 78032 & Methyl tert-butyl ether \\
34541 & 1,2-Dichloropropane & 34423 & Methylene chloride \\
34566 & 1,3-Dichlorobenzene & 77128 & Styrene \\
34571 & 1,4-Dichlorobenzene & 34475 & Tetrachloroethylene \\
34506 & 1,1,1-Trichloroethane & 34010 & Toluene \\
77652 & 1,1,2-Trichlorotrifluoroethane & 39180 & Trichloroethylene \\
34030 & Benzene & 34488 & Trichlorofluoromethane \\
32101 & Bromodichloromethane & 39175 & Vinyl chloride \\
32104 & Bromoform & 81551 & Xylene \\
32102 & Carbon tetrachloride & 77093 & cis-1,2-Dichloroethylene \\
34301 & Chlorobenzene & 34546 & trans-1,2-Dichloroethylene \\
32105 & Chlorodibromomethane & & \\
\hline
\end{tabular}




\section{BOTTOM-SEDIMENT CHEMISTRY}

Although the concentrations of 47 constituents in reservoir bottom sediment were quantified, the following discussion is limited to 11 selected trace elements. Data for all 47 constituents are included in table 11 at the back of this report.

Analytical results indicate that concentrations for most of the 11 selected trace elements are slightly to moderately enriched compared to samples of unaffected fine-grained sediments collected from several environments throughout the United States (Horowitz and others, 1996) (table 5). However, most concentrations are less than or about equal to background levels that have been determined from reservoir and streambed sediments in the South Platte River Basin (Heiny and Tate, 1997).
Currently, no Federal or State guidelines exist for concentrations of trace elements in bed sediment, but Canadian guidelines have been established by the Ontario Ministry of Environment for trace elements considered to be most toxic to aquatic life (Persaud and others, 1993). Comparison of trace-element concentrations in bottom sediment from Left Hand Valley Reservoir to the Canadian guidelines (table 5) indicates that concentrations for eight elements exceed the Lowest Effect Level (LEL) (arsenic, cadmium, chromium, copper, iron, lead, manganese, and zinc). The LEL indicates that the sediment is clean to marginally polluted, and most sediment-dwelling organisms are unaffected by the elevated concentrations. None of the trace-element concentrations exceeded the Severe Effect Level (SEL).

Table 5. Summary of selected trace-element concentrations in bottom sediments at site R2, Left Hand Valley Reservoir, July 27,1998

[Concentrations are in micrograms per gram unless noted as percent; \%, percent; PSQG, Provincial Sediment Quality Guideline; --, no data]

\begin{tabular}{|c|c|c|c|c|c|}
\hline Element & Concentration & $\begin{array}{l}\text { Background } \\
\text { concentration } \\
\text { for South } \\
\text { Platte River } \\
\text { Basin }^{1}\end{array}$ & $\begin{array}{c}\text { Nationwide } \\
\text { background } \\
\text { concentration }{ }^{2}\end{array}$ & $\begin{array}{c}\text { PSQG } \\
\text { Lowest Effect } \\
\text { Level }^{3}\end{array}$ & $\begin{array}{c}\text { PSQG } \\
\text { Severe Effect } \\
\text { Level }^{4}\end{array}$ \\
\hline Aluminum (\%) & 8.5 & 7.2 & 5.5 & -- & -- \\
\hline Arsenic & 11 & 7.8 & 7 & 6 & 33 \\
\hline Cadmium & 1.8 & 3.3 & -- & 0.6 & 9.5 \\
\hline Chromium & 86 & 60 & 51 & 26 & 110 \\
\hline Copper & 100 & 104 & 20 & 16 & 110 \\
\hline Iron $(\%)$ & 4.1 & 4.9 & 2.8 & 2.1 & 4.4 \\
\hline Lead & 120 & 100 & 23 & 31 & 250 \\
\hline Manganese & 590 & 1,260 & 600 & 460 & 1,100 \\
\hline Mercury & 0.12 & 0.03 & 0.05 & 0.2 & 2 \\
\hline Silver & 0.8 & 1.2 & -- & -- & -- \\
\hline Zinc & 370 & 450 & 88 & 120 & 820 \\
\hline
\end{tabular}

\footnotetext{
${ }^{1}$ Determined from reservoir and streambed sediments in the South Platte River Basin (from Heiny and Tate, 1997).

${ }^{2}$ Nationwide averages for fine-grained bed sediments from around the United States (from Horowitz and others, 1996).

${ }^{3}$ Marginally contaminated sediments, guideline developed by the Ontario Ministry of the Environment (Persaud and others, 1993).

${ }^{4}$ Highly contaminated sediments, guidelines set by the Ontario Ministry of the Environment (Persaud and others, 1993).
} 


\section{SUMMARY}

Water temperature, dissolved oxygen, and $\mathrm{pH}$ in Left Hand Valley Reservoir were uniform throughout the water column in winter (January and March 1998) but decreased with depth during spring and summer. In July and August 1998, anoxic (zero dissolved oxygen) conditions were measured near the bottom of the water column in some of the deepest areas of the reservoir. On any given date, dissolved-solids concentrations were relatively uniform throughout the water column, as indicated by measurements of specific conductance. Throughout the study, specific conductance varied between 80 and $297 \mu \mathrm{S} / \mathrm{cm}$ and the lowest values occurred in spring and summer (June-August 1998). Concentrations of dissolved solids and individual major ions did not exceed any water-quality standards or guidelines cited in this report.

Nitrogen in Left Hand Valley Reservoir predominantly was in the organic phase, and concentrations of total organic plus ammonia nitrogen ranged from 0.1 to $0.3 \mathrm{mg} / \mathrm{L}$. Median concentrations of dissolved inorganic nitrogen species were less than $0.02 \mathrm{mg} / \mathrm{L}$ for ammonia and $0.016 \mathrm{mg} / \mathrm{L}$ for nitrite plus nitrate nitrogen. Total phosphorus concentrations ranged from less than 0.01 to $0.059 \mathrm{mg} / \mathrm{L}$. Dissolved orthophosphorus concentrations almost always were less than the detection limit of $0.001 \mathrm{mg} / \mathrm{L}$.

Eight of the 18 trace elements analyzed for this study were not detected in any samples. Most median dissolved concentrations of the 10 detected trace elements were less than $10 \mu \mathrm{g} / \mathrm{L}$, and no concentrations exceeded any standards or guidelines that have been established for Left Hand Valley Reservoir or for treated drinking water. Dissolved manganese concentrations in bottom-water samples ranged between 2 and $478 \mu \mathrm{g} / \mathrm{L}$ and increased with decreasing dissolved oxygen concentrations.

In January and July 1998, samples were collected for analysis of VOCs at sites where organiccompound sampling had previously been conducted in March 1996. No VOCs or NDMA, a metabolite of the rocket fuel component 1,1-dimethylhydrazine, was detected in any of the four samples.

Comparison of selected trace-element concentrations in reservoir bottom sediments to Canadian sediment guidelines indicates that the reservoir sediments are clean to marginally polluted with respect to eight elements (arsenic, cadmium, chromium, copper, iron, lead, manganese, and zinc). However, the traceelement concentrations were comparable to back- ground concentrations determined from reservoir and streambed sediments in the South Platte River Basin.

\section{REFERENCES}

Arbogast, B.F., ed., 1990, Quality assurance manual for the Branch of Geochemistry: U.S. Geological Survey Open-File Report 90-668, 184 p.

Colorado Department of Public Health and Environment, 1996, Classifications and numeric standards for the South Platte River Basin, Laramie River Basin, Republican River Basin, and Smoky Hill River Basin 3.8.0: Denver, Water Quality Control Commission 5 CCR $1002-8,148 \mathrm{p}$.

Faires, L.M., 1993, Methods of analysis by the U.S. Geological Survey National Water Quality Laboratory - Determination of metals in water by inductively coupled plasma-mass spectrometry: U.S. Geological Survey Open-File Report 92-634, $28 \mathrm{p}$.

Fishman, M.J., 1993, Methods of analysis by the U.S. Geological Survey National Water Quality Laboratory-Determination of inorganic and organic constituents in water and fluvial sediments: U.S. Geological Survey Open-File Report 93-125, 217 p.

Fishman, M.J., and Friedman, L.C., 1989, Methods for determination of inorganic substances in water and fluvial sediments: U.S. Geological Survey Techniques of Water-Resources Investigations, book 5, chap. A1, $545 \mathrm{p}$.

Heiny, J.S., and Tate, C.M., 1997, Concentration, distribution, and comparison of selected trace elements in bed sediment and fish tissue in the South Platte River Basin, USA, 1992-1993: Archives of Environmental Contamination and Toxicology, v. 32, p. 246-259.

Horowitz, A.J., Demas, C.R., Fitzgerald, K.K., Miller, T.L., and Rickert, D.A., 1994, U.S. Geological Survey protocol for the collection and processing of surfacewater samples for the subsequent determination of inorganic constituents in filtered water: U.S. Geological Survey Open-File Report 94-539, 57 p.

Horowitz, A.J., Robbins, J.A., Elrick, K.A., and Cook, R.B., 1996, Bed sediment-trace element geochemistry of Terrace Reservoir, near Summitville, southwestern Colorado: U.S. Geological Survey Open-File Report 96-344, 41 p.

Patton, C.J., and Truitt, E.P., 1992, Methods of analysis by the U.S. Geological Survey National Water Quality Laboratory-Determination of total phosphorus by a Kjeldahl digestion method and an automated colorimetric finish that includes dialysis: U.S. Geological Survey Open-File Report 92-146, 39 p. 
Persaud, D., Jaagumagi, R., and Hayton, A., 1993, Guidelines for the protection and management of aquatic sediment quality in Ontario: Toronto, Ontario Ministry of the Environment, $24 \mathrm{p}$.

Porter, S.D., Cuffney, T.F., Gurtz, M.E., and Meador, M.R., 1993, Methods for collecting algal samples as part of the National Water-Quality Assessment Program: U.S. Geological Survey Open-File Report 93-409, $39 \mathrm{p}$.

Rose, D.L., and Schroeder, M.P., 1995, Methods of analysis by the U.S. Geological Survey National Water Quality Laboratory-Determination of volatile organic compounds in water by purge and trap capillary gas chromatography/mass spectrometry: U.S. Geological Survey Open-File Report 94-708, 26 p.

Shelton, L.R., 1994, Field guide for collecting and processing stream-water samples for the National
Water-Quality Assessment Program: U.S. Geological Survey Open-File Report 94-455, 42 p.

Trimble, D.E., 1975, Geologic map of the Niwot quadrangle, Boulder County, Colorado: U.S. Geological Survey Geologic Quadrangle Map GQ-1229, 1 sheet, scale $1: 24,000$.

U.S. Department of the Interior, 1994, Salinity update: Denver, Bureau of Reclamation, Colorado River Salinity Program Coordinator, $17 \mathrm{p}$.

U.S. Environmental Protection Agency, 1986, Quality criteria for water, 1986: U.S. Environmental Protection Agency Report 440/5-86-001, [variously paged].

U.S. Environmental Protection Agency, 1996, Drinking water regulations and health advisories, October 1996: U.S. Environmental Protection Agency, Office of Water, EPA 822-B-96-002, 11 p. 


\section{WATER-QUALITY AND BOTTOM-SEDIMENT-CHEMISTRY DATA}


Table 6. Profile of onsite water-quality measurements for site R1, Left Hand Valley Reservoir near south dam, January-August 1998

$[\mu \mathrm{S} / \mathrm{cm}$, microsiemens per centimeter at 25 degrees Celsius; deg, degrees; $\mathrm{C}$, Celsius; $\mathrm{mg} / \mathrm{L}$, milligrams per liter]

\begin{tabular}{|c|c|c|c|c|c|c|c|c|c|}
\hline $\begin{array}{l}\text { Depth } \\
\text { (feet) }\end{array}$ & $\begin{array}{c}\text { Specific } \\
\text { conduct- } \\
\text { ance } \\
(\mu \mathrm{S} / \mathrm{cm})\end{array}$ & $\begin{array}{c}\text { pH } \\
\text { (units) }\end{array}$ & $\begin{array}{c}\text { Temper- } \\
\text { ature } \\
(\operatorname{deg} C)\end{array}$ & $\begin{array}{c}\text { Dissolved } \\
\text { oxygen } \\
\text { (mg/L) }\end{array}$ & $\begin{array}{l}\text { Depth } \\
\text { (feet) }\end{array}$ & $\begin{array}{c}\text { Specific } \\
\text { conduct- } \\
\text { ance } \\
(\mu \mathrm{S} / \mathrm{cm})\end{array}$ & $\underset{\text { (units) }}{\mathrm{pH}}$ & $\begin{array}{c}\text { Temper- } \\
\text { ature } \\
\text { (deg C) }\end{array}$ & $\begin{array}{c}\text { Dissolved } \\
\text { oxygen } \\
\text { (mg/l) }\end{array}$ \\
\hline 0.5 & 213 & 7.8 & 3.0 & 10.4 & 18.0 & 213 & 7.9 & 3.3 & 10.4 \\
\hline 1.0 & 213 & 7.8 & 2.9 & 10.4 & 19.0 & 214 & 7.9 & 3.3 & 10.4 \\
\hline 4.0 & 214 & 7.9 & 3.0 & 10.4 & 22.0 & 214 & 7.9 & 3.4 & 10.5 \\
\hline 5.0 & 213 & 7.9 & 3.0 & 10.4 & 23.0 & 214 & 7.9 & 3.4 & 10.5 \\
\hline 6.0 & 214 & 7.9 & 3.2 & 10.4 & 24.0 & 214 & 7.9 & 3.4 & 10.5 \\
\hline 7.0 & 213 & 7.9 & 3.2 & 10.4 & 25.0 & 214 & 7.9 & 3.4 & 10.5 \\
\hline 11.0 & 213 & 7.9 & 3.3 & 10.4 & 29.0 & 214 & 7.9 & 3.4 & 10.4 \\
\hline 12.0 & 214 & 7.9 & 3.3 & 10.4 & 30.0 & 214 & 7.9 & 3.4 & 10.4 \\
\hline 13.0 & 214 & 7.9 & 3.3 & 10.4 & 31.0 & 214 & 7.9 & 3.4 & 10.4 \\
\hline 14.0 & 214 & 7.9 & 3.3 & 10.4 & 32.0 & 215 & 7.9 & 3.5 & 10.4 \\
\hline 15.0 & 214 & 7.9 & 3.3 & 10.4 & 33.0 & 215 & 7.9 & 3.6 & 10.4 \\
\hline 16.0 & 213 & 7.9 & 3.3 & 10.4 & 33.7 & 218 & 7.9 & 3.7 & 10.2 \\
\hline 17.0 & 213 & 7.9 & 3.3 & 10.4 & & & & & \\
\hline \multicolumn{10}{|c|}{ March 10, 1998, Secchi-disc depth, 5.8 feet } \\
\hline 1.0 & 234 & 7.8 & 2.7 & 10.4 & 19.5 & 235 & 7.9 & 3.5 & 10.9 \\
\hline 2.0 & 235 & 7.8 & 2.7 & 10.4 & 20.5 & 235 & 7.9 & 3.6 & 10.9 \\
\hline 9.0 & 236 & 7.9 & 3.2 & 10.6 & 27.0 & 236 & 7.9 & 3.7 & 11.0 \\
\hline 10.0 & 235 & 7.9 & 3.3 & 10.6 & 28.0 & 236 & 7.9 & 3.7 & 11.1 \\
\hline 11.0 & 236 & 7.9 & 3.3 & 10.7 & 29.0 & 237 & 7.9 & 3.7 & 11.1 \\
\hline 12.0 & 235 & 7.9 & 3.3 & 10.8 & 30.0 & 236 & 7.9 & 3.7 & 11.1 \\
\hline 13.0 & 236 & 7.9 & 3.1 & 10.9 & 31.0 & 236 & 7.9 & 3.7 & 11.1 \\
\hline 14.0 & 236 & 7.9 & 3.1 & 10.9 & 32.0 & 237 & 7.9 & 3.7 & 11.1 \\
\hline 15.0 & 235 & 7.9 & 3.2 & 10.9 & 33.0 & 236 & 7.9 & 3.7 & 11.0 \\
\hline 16.0 & 235 & 7.9 & 3.2 & 10.9 & 34.0 & 237 & 7.9 & 3.8 & 11.0 \\
\hline 17.5 & 236 & 7.9 & 3.5 & 10.9 & 34.6 & 239 & 7.9 & 3.7 & 10.9 \\
\hline 18.5 & 236 & 7.9 & 3.5 & 10.9 & & & & & \\
\hline
\end{tabular}


Table 6. Profile of onsite water-quality measurements for site R1, Left Hand Valley Reservoir near south dam, January-August 1998-Continued

[ $\mu \mathrm{S} / \mathrm{cm}$, microsiemens per centimeter at 25 degrees Celsius; deg, degrees; C, Celsius; mg/L, milligrams per liter]

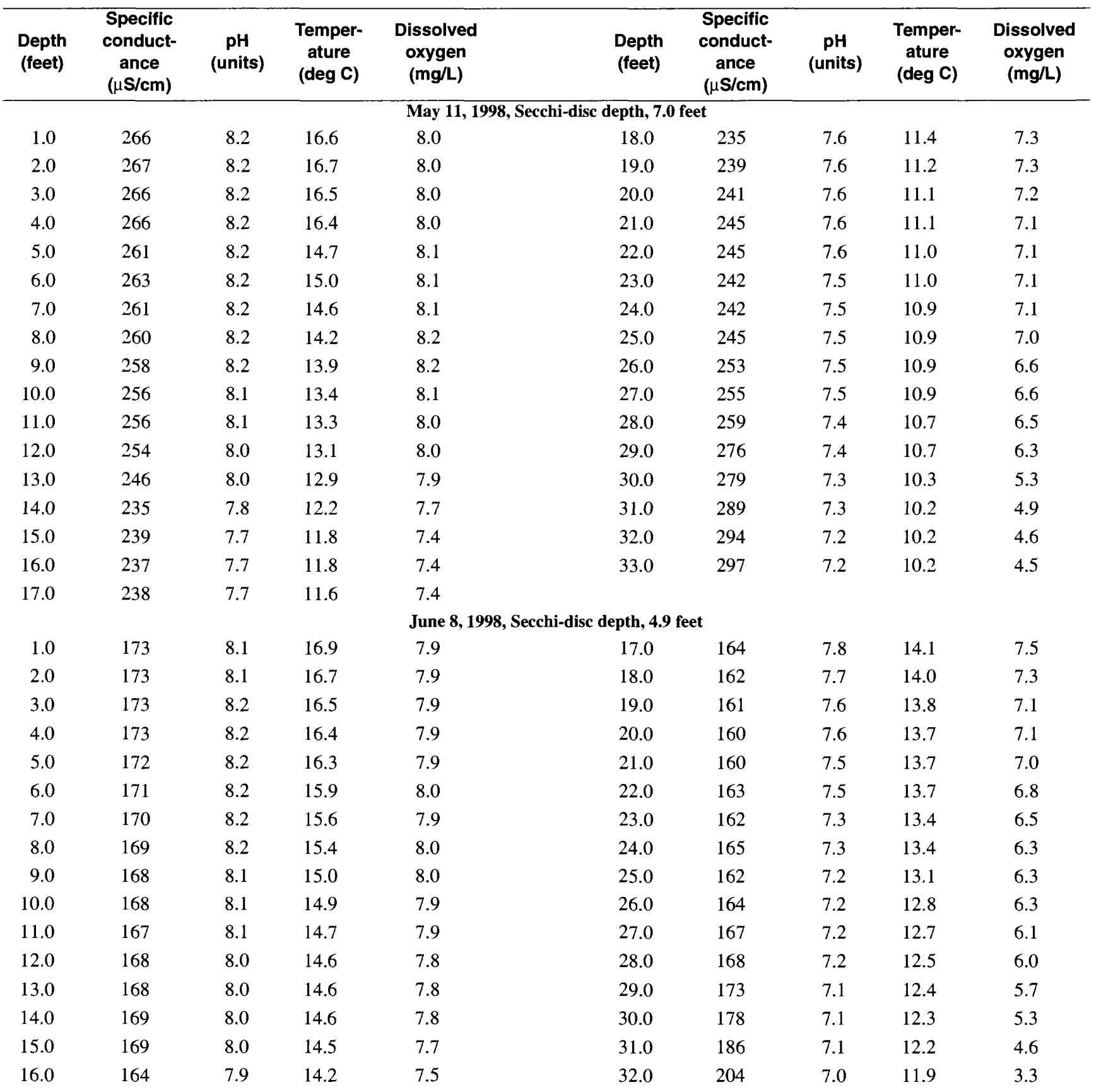


Table 6. Profile of onsite water-quality measurements for site R1, Left Hand Valley Reservoir near south dam, January-August 1998-Continued

[ $\mu \mathrm{S} / \mathrm{cm}$, microsiemens per centimeter at 25 degrees Celsius; deg, degrees; C, Celsius; mg/L, milligrams per liter]

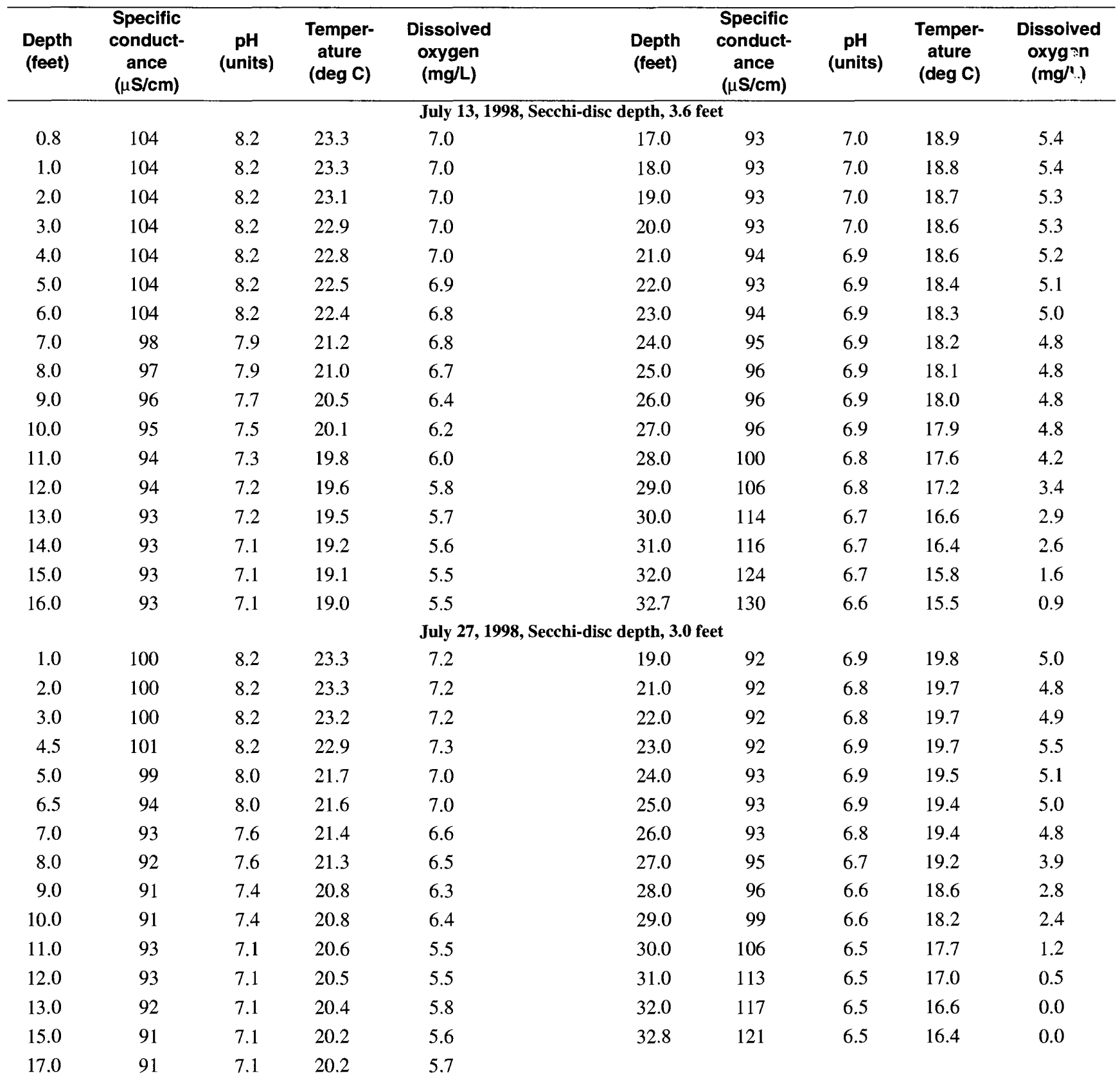


Table 6. Profile of onsite water-quality measurements for site R1, Left Hand Valley Reservoir near south dam, January-August 1998-Continued

[ $\mu \mathrm{S} / \mathrm{cm}$, microsiemens per centimeter at 25 degrees Celsius; deg, degrees; C, Celsius; mg/L, milligrams per liter]

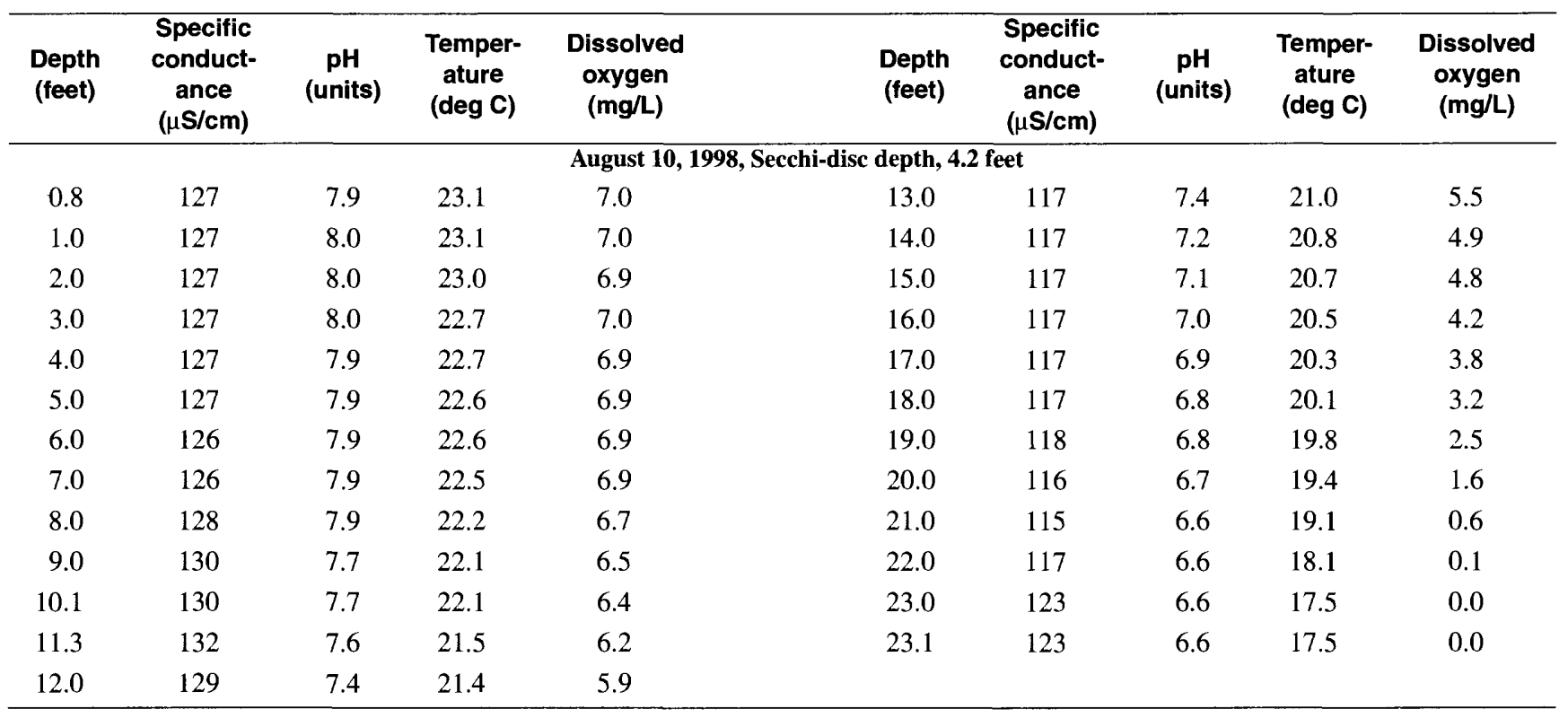


Table 7. Profile of onsite water-quality measurements for site R2, Left Hand Valley Reservoir near north dam, January-August 1998

[ $\mu \mathrm{S} / \mathrm{cm}$, microsiemens per centimeter at 25 degrees Celsius; deg, degrees; C, Celsius; mg/L, milligrams per liter]

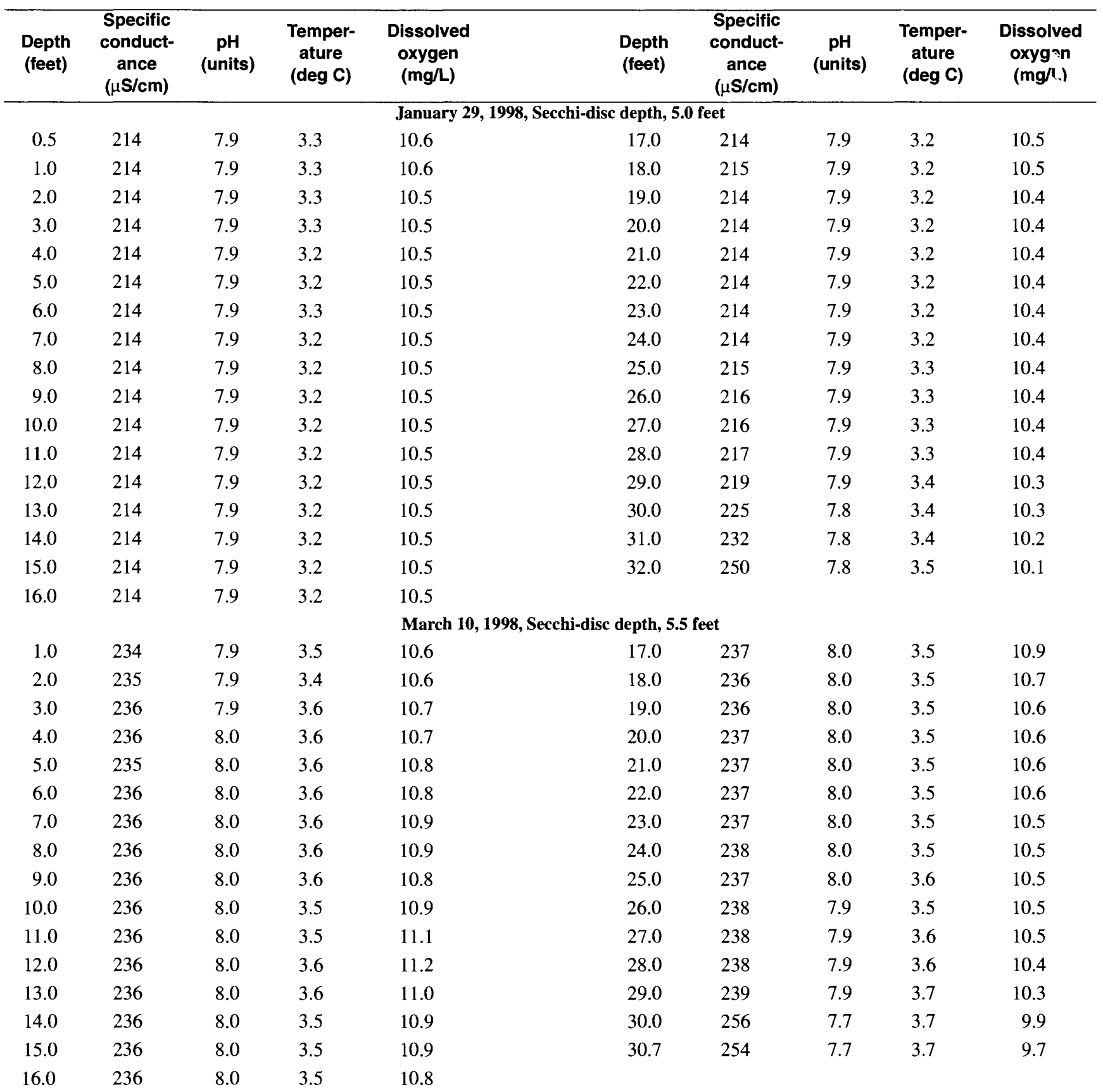


Table 7. Profile of onsite water-quality measurements for site R2, Left Hand Valley Reservoir near north dam, January-August 1998-Continued

[ $\mu \mathrm{S} / \mathrm{cm}$, microsiemens per centimeter at 25 degrees Celsius; deg, degrees; $\mathrm{C}$, Celsius; mg/L, milligrams per liter]

\begin{tabular}{|c|c|c|c|c|c|c|c|c|c|}
\hline $\begin{array}{l}\text { Depth } \\
\text { (feet) }\end{array}$ & $\begin{array}{c}\text { Specific } \\
\text { conduct- } \\
\text { ance } \\
(\mu \mathrm{S} / \mathrm{cm})\end{array}$ & $\underset{\text { (unlts) }}{\mathrm{pH}}$ & $\begin{array}{l}\text { Temper- } \\
\text { ature } \\
\text { (deg C) }\end{array}$ & $\begin{array}{c}\text { Dlssolved } \\
\text { oxygen } \\
\text { (mg/L) }\end{array}$ & $\begin{array}{l}\text { Depth } \\
\text { (feet) }\end{array}$ & $\begin{array}{c}\text { Specific } \\
\text { conduct- } \\
\text { ance } \\
(\mu \mathrm{S} / \mathrm{cm})\end{array}$ & $\underset{\text { (units) }}{\mathrm{pH}}$ & $\begin{array}{l}\text { Temper- } \\
\text { ature } \\
\text { (deg C) }\end{array}$ & $\begin{array}{c}\text { Dissolved } \\
\text { oxygen } \\
\text { (mg/L) }\end{array}$ \\
\hline \multicolumn{10}{|c|}{ May 11,1998 , Secchi-disc depth, 6.5 feet } \\
\hline 0.5 & 264 & 8.2 & 16.0 & 8.1 & 17.0 & 231 & 7.7 & 11.6 & 7.5 \\
\hline 1.0 & 264 & 8.2 & 16.2 & 8.1 & 18.0 & 234 & 7.7 & 11.5 & 7.5 \\
\hline 2.0 & 263 & 8.3 & 15.9 & 8.1 & 19.0 & 233 & 7.7 & 11.4 & 7.4 \\
\hline 3.0 & 262 & 8.3 & 15.6 & 8.1 & 20.0 & 232 & 7.7 & 11.2 & 7.4 \\
\hline 4.0 & 261 & 8.3 & 15.2 & 8.1 & 21.0 & 229 & 7.7 & 11.2 & 7.4 \\
\hline 5.0 & 254 & 8.3 & 15.1 & 8.2 & 22.0 & 232 & 7.7 & 11.2 & 7.4 \\
\hline 6.0 & 252 & 8.3 & 14.9 & 8.2 & 23.0 & 233 & 7.6 & 11.1 & 7.3 \\
\hline 7.0 & 251 & 8.2 & 14.7 & 8.2 & 24.0 & 233 & 7.6 & 11.0 & 7.2 \\
\hline 8.0 & 255 & 8.3 & 14.4 & 8.3 & 25.0 & 233 & 7.6 & 10.9 & 7.2 \\
\hline 9.0 & 262 & 8.3 & 14.2 & 8.3 & 26.0 & 229 & 7.6 & 10.9 & 7.2 \\
\hline 10.0 & 259 & 8.3 & 14.0 & 8.2 & 27.0 & 237 & 7.5 & 10.7 & 7.0 \\
\hline 11.0 & 258 & 8.2 & 13.6 & 8.2 & 28.0 & 245 & 7.5 & 10.6 & 6.6 \\
\hline 12.0 & 253 & 8.1 & 13.3 & 8.0 & 29.0 & 247 & 7.5 & 10.6 & 6.5 \\
\hline 13.0 & 249 & 8.1 & 13.0 & 7.9 & 30.0 & 251 & 7.4 & 10.5 & 6.1 \\
\hline 14.0 & 239 & 7.9 & 12.4 & 7.8 & 31.0 & 252 & 7.4 & 10.5 & 6.0 \\
\hline 15.0 & 239 & 7.9 & 12.4 & 7.7 & 32.0 & 255 & 7.4 & 10.5 & 5.8 \\
\hline 16.0 & 232 & 7.8 & 11.7 & 7.6 & 33.0 & 257 & 7.3 & 10.4 & 5.4 \\
\hline \multicolumn{10}{|c|}{ June 8, 1998, Secchi-disc depth, 5.1 feet } \\
\hline 1.0 & 173 & 8.2 & 17.0 & 8.1 & 16.0 & 164 & 7.8 & 14.1 & 7.5 \\
\hline 2.0 & 172 & 8.2 & 16.8 & 8.0 & 17.0 & 162 & 7.8 & 14.0 & 7.4 \\
\hline 3.0 & 172 & 8.2 & 16.3 & 8.0 & 18.0 & 160 & 7.7 & 13.9 & 7.3 \\
\hline 4.0 & 172 & 8.2 & 16.2 & 8.0 & 19.0 & 159 & 7.7 & 13.8 & 7.3 \\
\hline 5.0 & 171 & 8.2 & 16.1 & 8.0 & 20.0 & 159 & 7.6 & 13.8 & 7.3 \\
\hline 6.0 & 171 & 8.2 & 16.0 & 8.1 & 21.0 & 159 & 7.6 & 13.8 & 7.3 \\
\hline 7.0 & 171 & 8.2 & 15.9 & 8.0 & 22.0 & 159 & 7.6 & 13.8 & 7.3 \\
\hline 8.0 & 170 & 8.2 & 15.6 & 8.0 & 23.0 & 149 & 7.6 & 13.5 & 7.3 \\
\hline 9.0 & 168 & 8.2 & 14.9 & 8.0 & 24.0 & 150 & 7.6 & 13.4 & 7.2 \\
\hline 10.0 & 167 & 8.2 & 14.8 & 8.0 & 25.0 & 150 & 7.5 & 13.4 & 7.1 \\
\hline 11.0 & 167 & 8.2 & 14.7 & 8.0 & 26.0 & 150 & 7.4 & 13.3 & 7.1 \\
\hline 12.0 & 168 & 8.1 & 14.6 & 7.8 & 27.0 & 146 & 7.4 & 13.2 & 7.0 \\
\hline 13.0 & 167 & 8.1 & 14.5 & 7.8 & 28.0 & 150 & 7.4 & 13.0 & 6.7 \\
\hline 14.0 & 167 & 8.0 & 14.5 & 7.7 & 29.0 & 154 & 7.3 & 12.8 & 6.4 \\
\hline 15.0 & 165 & 7.9 & 14.3 & 7.6 & 30.0 & 157 & 7.2 & 12.7 & 6.1 \\
\hline
\end{tabular}


Table 7. Profile of onsite water-quality measurements for site R2, Left Hand Valley Reservoir near north dam, January-August 1998-Continued

[ $\mu \mathrm{S} / \mathrm{cm}$, microsiemens per centimeter at 25 degrees Celsius; deg, degrees; C, Celsius; $\mathrm{mg} / \mathrm{L}$, milligrams per liter]

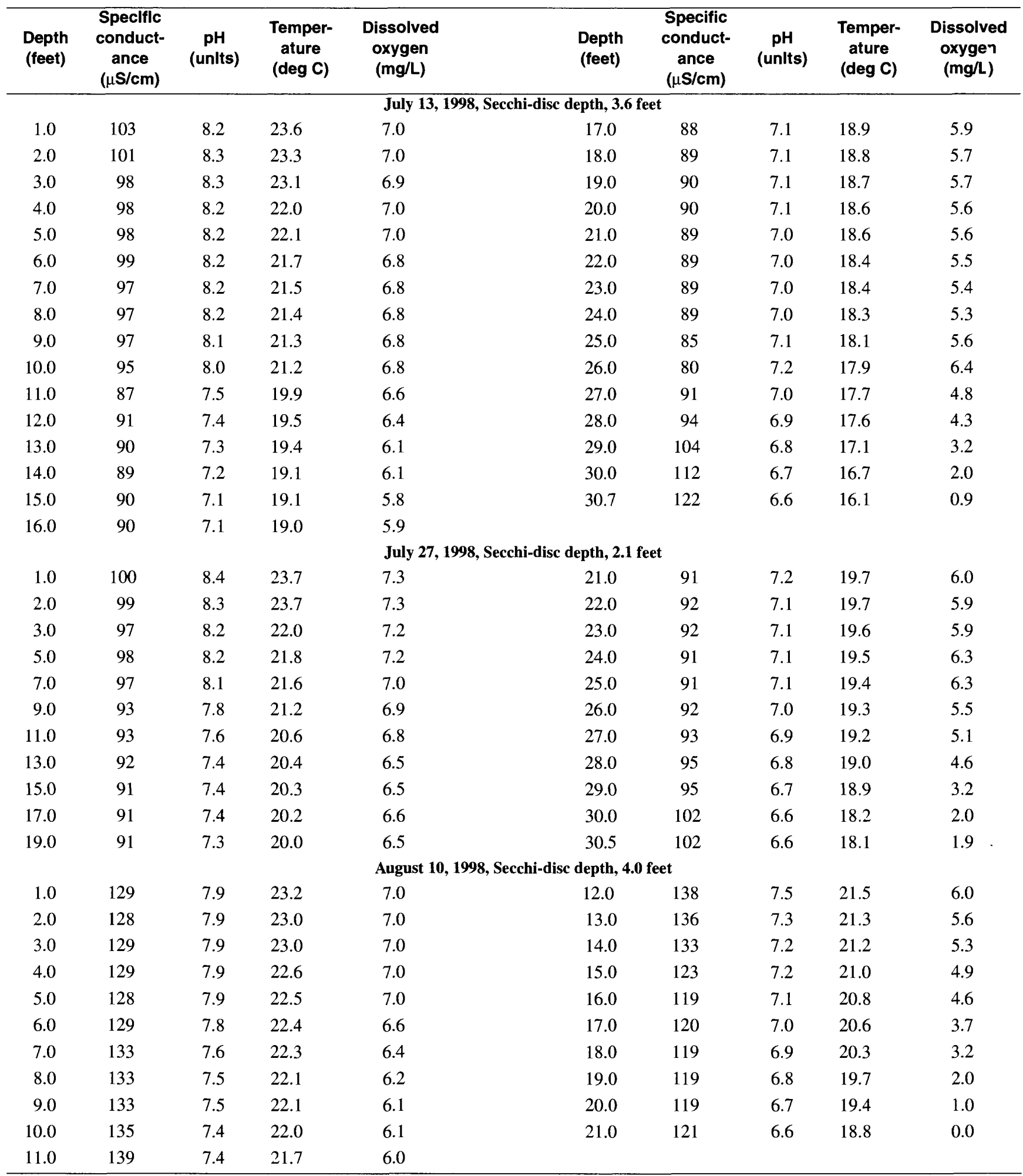


Table 8. Water-quality data for major ions, alkalinity, dissolved solids, nutrients, organic carbon, fecal coliform bacteria, and chlorophyll $a$ and $b$, Left Hand Valley Reservoir, January-August 1998

[MG/L, milligrams per liter; DEG. C, degrees Celsius; NO2+NO3, nitrite plus nitrate; MPN, most probable number; CHLOR, chlorophyll; UG/L, micrograms per liter; --, no data; <, less than]

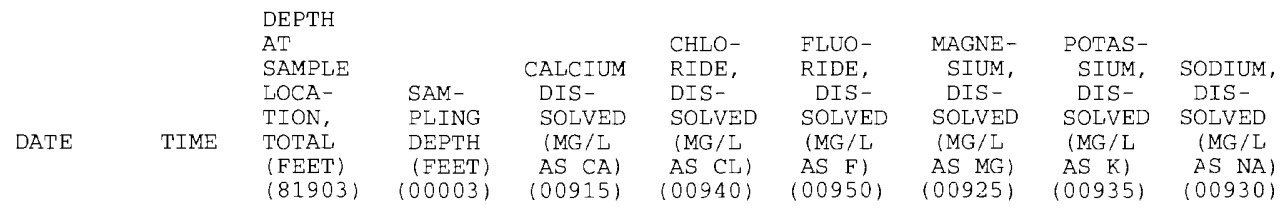

SITE R1， 400546105154900 LEFT HAND VALLEY RESERVOIR NEAR SOUTH DAM

\begin{tabular}{|c|c|c|c|c|c|c|c|c|c|}
\hline $\begin{array}{c}\text { JAN } 1998 \\
29 \ldots \\
29 \ldots\end{array}$ & $\begin{array}{l}1220 \\
1240\end{array}$ & $\begin{array}{l}34.2 \\
34.2\end{array}$ & $\begin{array}{r}0-10.6 \\
32.0\end{array}$ & $\begin{array}{l}25 \\
25\end{array}$ & $\begin{array}{l}2.9 \\
2.8\end{array}$ & $\begin{array}{l}0.5 \\
0.5\end{array}$ & $\begin{array}{l}7.2 \\
7.2\end{array}$ & $\begin{array}{l}0.8 \\
0.8\end{array}$ & $\begin{array}{l}5.8 \\
5.8\end{array}$ \\
\hline \multicolumn{10}{|l|}{ MAR } \\
\hline 10. & $\begin{array}{l}1015 \\
1030\end{array}$ & $\begin{array}{l}35.1 \\
35.1\end{array}$ & $\begin{array}{r}0-11.6 \\
32.0\end{array}$ & $\begin{array}{l}28 \\
28\end{array}$ & $\begin{array}{l}3.3 \\
3.3\end{array}$ & $\begin{array}{l}0.5 \\
0.5\end{array}$ & $\begin{array}{l}7.7 \\
7.8\end{array}$ & $\begin{array}{l}0.8 \\
0.8\end{array}$ & $\begin{array}{l}6.5 \\
6.6\end{array}$ \\
\hline \multicolumn{10}{|l|}{ MAY } \\
\hline $11 \ldots$ & 1000 & 33.0 & $0-14.0$ & 29 & 5.9 & 0.9 & 8.7 & 1.1 & 9.1 \\
\hline 11. & 1015 & 33.0 & 30.0 & 30 & 6.0 & 0.8 & 8.9 & 1.1 & 9.3 \\
\hline & 1020 & 32.8 & $0-9.8$ & JUNE & 4.0 & 0.6 & 5.4 & 0.9 & 5.9 \\
\hline $08 \ldots$ & 1040 & 32.8 & 30.0 & 19 & 3.9 & 0.6 & 5.5 & 0.9 & 6.0 \\
\hline & 1110 & 33.6 & $0-7.2$ & 12 & 2.0 & 0.4 & 3.1 & 0.6 & 3.2 \\
\hline $13 \ldots$ & 1130 & 33.6 & 30.5 & 12 & 2.1 & 0.4 & 3.2 & 0.6 & 3.3 \\
\hline $27 \cdots$ & 1210 & 33.2 & $0-6.0$ & 12 & 1.6 & 0.3 & 2.8 & 0.6 & 2.9 \\
\hline \multicolumn{10}{|l|}{ AUG } \\
\hline & 1050 & 23.5 & -8.4 & 15 & 2.1 & 0.4 & 3.7 & 0.6 & 3.8 \\
\hline & 1110 & 23.5 & 21.5 & 13 & 2.0 & 0.4 & 3.4 & 0.7 & 3.3 \\
\hline
\end{tabular}

SITE R2, 400600105154400 LEFT HAND VALLEY RESERVOIR NEAR NORTH DAM

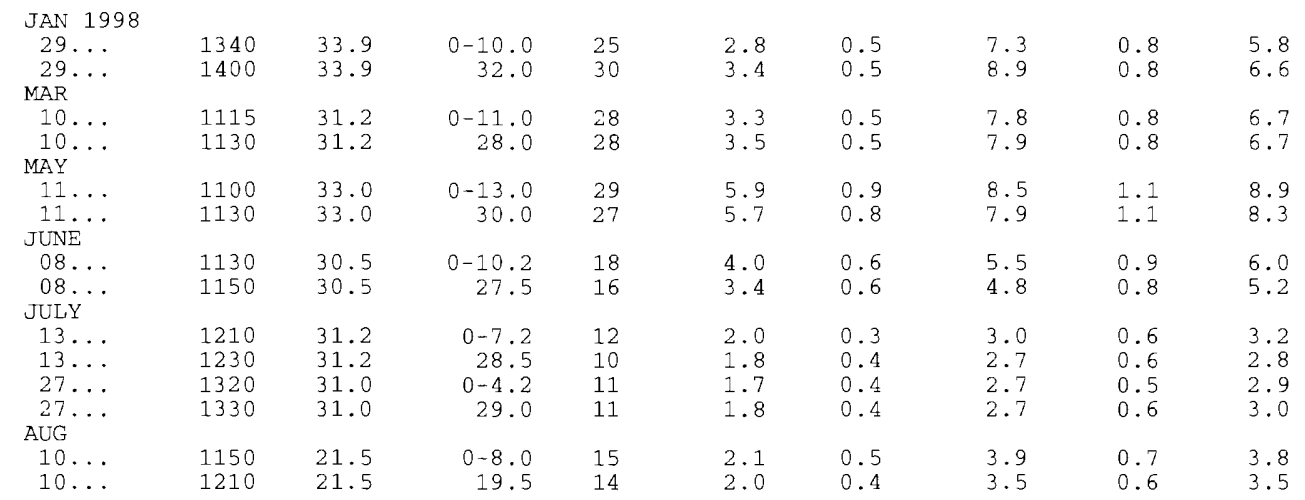


Table 8. Water-quality data for major ions, alkalinity, dissolved solids, nutrients, organic carbon, fecal coliform bacteria, and chlorophyll $a$ and $b$, Left Hand Valley Reservoir, January-August 1998-Continued

[MG/L, milligrams per liter; DEG. C, degrees Celsius; NO2+NO3, nitrite plus nitrate; MPN, most probable number; CHLOR, chlorophyll; UG/L, microg *ams per liter; --, no data; <, less than]

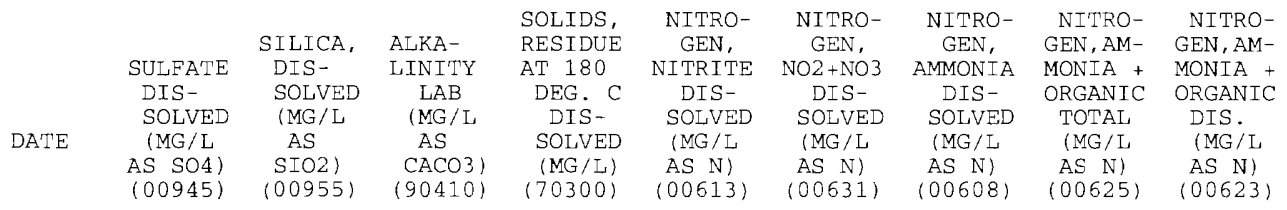

SITE R1, 400546105154900 LEFT HAND VALLEY RESERVOIR NEAR SOUTH DAM

\begin{tabular}{|c|c|c|c|c|c|c|c|c|c|}
\hline $\begin{array}{l}29 \ldots \\
29 \ldots\end{array}$ & $\begin{array}{l}44 \\
44\end{array}$ & $\begin{array}{l}5.6 \\
5.6\end{array}$ & $\begin{array}{l}61 \\
60\end{array}$ & $\begin{array}{l}142 \\
139\end{array}$ & $\begin{array}{l}<0.01 \\
<0.01\end{array}$ & $\begin{array}{l}<0.05 \\
<0.05\end{array}$ & $\begin{array}{l}0.04 \\
0.03\end{array}$ & $\begin{array}{l}0.1 \\
0.2\end{array}$ & $\begin{array}{l}<0.1 \\
<0.1\end{array}$ \\
\hline \multicolumn{10}{|l|}{ MAR } \\
\hline $\begin{array}{l}10 \ldots \\
10 \ldots\end{array}$ & $\begin{array}{l}49 \\
49\end{array}$ & $\begin{array}{l}5.3 \\
5.3\end{array}$ & $\begin{array}{l}64 \\
64\end{array}$ & $\begin{array}{l}149 \\
148\end{array}$ & $\begin{array}{l}<0.01 \\
<0.01\end{array}$ & $\begin{array}{l}<0.05 \\
<0.05\end{array}$ & $\begin{array}{l}<0.02 \\
<0.02\end{array}$ & 0.1 & $<0.1$ \\
\hline \multicolumn{10}{|l|}{ MAY } \\
\hline $11 \ldots$ & 58 & 9.3 & 57 & 165 & $<0.001$ & 0.012 & 0.009 & 0.2 & 0.1 \\
\hline $11 \ldots$ & 62 & 9.7 & 59 & 174 & $<0.001$ & 0.048 & 0.030 & 0.3 & $<0.1$ \\
\hline \multicolumn{10}{|l|}{ JUNE } \\
\hline $08 \ldots$ & 34 & 7.4 & 42 & 116 & 0.005 & 0.006 & 0.002 & 0.2 & $<0.1$ \\
\hline $08 \ldots$ & 35 & 8.6 & 43 & 118 & 0.003 & 0.037 & 0.025 & 0.2 & 0.1 \\
\hline \multicolumn{3}{|l|}{ JULY } & 31 & 63 & & $<0$ & 0.004 & 0.2 & \\
\hline 13. & 14 & 6.5 & 31 & 66 & 0.004 & 0.008 & 0.010 & 0.3 & \\
\hline 27. & 13 & 5.3 & 30 & 66 & $<0.001$ & $<0.005$ & $<0.002$ & 0.2 & \\
\hline 27. & 13 & 6.3 & 32 & 65 & 0.003 & 0.015 & 0.024 & 0.3 & 0.1 \\
\hline \multicolumn{10}{|l|}{ AUG } \\
\hline $10 \ldots$ & 19 & 5.7 & 37 & 81 & $<0.001$ & $<0.005$ & 0.003 & 0.2 & 0.1 \\
\hline 10. & 14 & 6.9 & 37 & 76 & $<0.001$ & $<0.005$ & 0.057 & 0.3 & 0.2 \\
\hline
\end{tabular}

SITE R2, 400600105154400 LEFT HAND VALLEY RESERVOIR NEAR NORTH DAM

\begin{tabular}{|c|c|c|c|c|c|c|c|c|c|}
\hline \multicolumn{10}{|c|}{ JAN 1998} \\
\hline $\begin{array}{r}29 \ldots \\
29 \ldots\end{array}$ & $\begin{array}{l}45 \\
55\end{array}$ & $\begin{array}{l}5.4 \\
5.5\end{array}$ & $\begin{array}{l}61 \\
68\end{array}$ & $\begin{array}{l}141 \\
167\end{array}$ & $\begin{array}{l}0.12 \\
0.01\end{array}$ & $\begin{array}{r}0.14 \\
<0.05\end{array}$ & $\begin{array}{l}0.04 \\
0.03\end{array}$ & $\begin{array}{l}0.2 \\
0.3\end{array}$ & $\begin{array}{r}<0.1 \\
0.1\end{array}$ \\
\hline \multicolumn{10}{|l|}{ MAR } \\
\hline $10 \ldots$ & 49 & 5.3 & 64 & 150 & $<0.01$ & $<0.05$ & $<0.02$ & 0.1 & $<0.1$ \\
\hline $10 \ldots$ & 50 & 5.5 & 65 & 153 & $<0.01$ & $<0.05$ & $<0.02$ & 0.1 & $<0.1$ \\
\hline \multicolumn{10}{|l|}{ MAY } \\
\hline $11 \ldots$ & 58 & 9.2 & 57 & 164 & $<0.001$ & 0.014 & 0.012 & 0.3 & 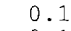 \\
\hline \multirow{2}{*}{\multicolumn{10}{|c|}{ JUNE }} \\
\hline & & & & & & & & & \\
\hline $08 \ldots$ & 34 & 7.5 & 42 & 113 & 0.002 & $<0.005$ & $<0.002$ & 0.2 & $<0.1$ \\
\hline \multirow{2}{*}{\multicolumn{10}{|c|}{ JULY }} \\
\hline & & & & & & & & & \\
\hline $13 \ldots$ & 14 & 5.5 & 30 & 63 & 0.003 & $<0.005$ & 0.006 & 0.2 & 0 \\
\hline $13 \ldots$ & 12 & 5.8 & 29 & 58 & 0.006 & 0.016 & 0.020 & 0.2 & $<0$. \\
\hline $27 \ldots$ & 14 & 5.4 & 30 & 63 & 0.001 & $<0.005$ & 0.002 & 0.3 & $<0.1$ \\
\hline 27. & 14 & 6.2 & 28 & 64 & 0.003 & 0.018 & 0.016 & 0.3 & 0 \\
\hline \multicolumn{10}{|l|}{ AUG } \\
\hline 10. & 18 & 5.8 & 40 & 83 & $<0.001$ & $<0.005$ & 0.004 & 0.2 & 0 \\
\hline & 16 & 6.2 & 37 & 78 & $<0.001$ & $<0.005$ & 0.035 & 0.2 & \\
\hline
\end{tabular}


Table 8. Water-quality data for major ions, alkalinity, dissolved solids, nutrients, organic carbon, fecal coliform bacteria, and chlorophyll $a$ and $b$, Left Hand Valley Reservoir, January-August 1998-Continued

[MG/L, milligrams per liter; DEG. C, degrees Celsius; NO2+NO3, nitrite plus nitrate; MPN, most probable number; CHLOR, chlorophyll; UG/_, micrograms per liter; --, no data; <, less than]

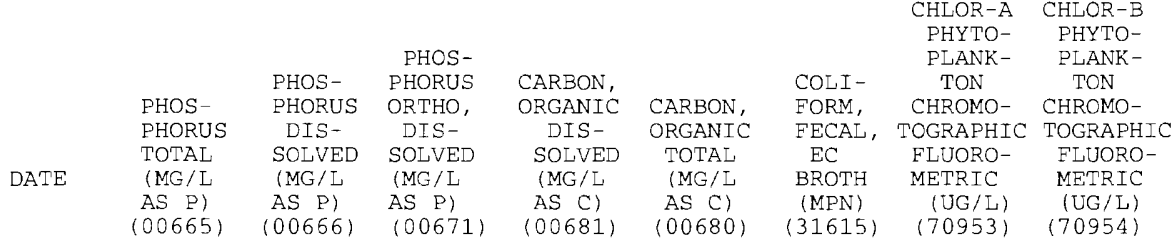

SITE R1, 400546105154900 LEFT HAND VALLEY RESERVOIR NEAR SOUTH DAM

\begin{tabular}{|c|c|c|c|c|c|c|c|c|}
\hline \multicolumn{9}{|c|}{ JAN 1998} \\
\hline $29 \ldots$ & 0.02 & $<0.01$ & 0.01 & 1.8 & 2.0 & $<2$ & 1.3 & $<0.1$ \\
\hline \multicolumn{9}{|l|}{ MAR } \\
\hline $10 \ldots$ & $<0.01$ & $<0.01$ & $<0.01$ & 1.8 & 2.6 & $<2$ & 1.8 & $<0.1$ \\
\hline $10 \ldots$ & $<0.01$ & $<0.01$ & $<0.01$ & 1.7 & 2.2 & $\cdots$ & -- & -- \\
\hline \multicolumn{9}{|l|}{ MAY } \\
\hline $11 \ldots$ & 0.014 & 0.004 & $<0.001$ & 3.5 & 4.2 & $<2$ & 1.0 & $<0.1$ \\
\hline $11 \ldots$ & 0.025 & 0.004 & $<0.001$ & 3.3 & 4.4 & -- & -- & -- \\
\hline \multicolumn{9}{|l|}{ JUNE } \\
\hline $08 \ldots$ & 0.013 & 0.002 & 0.001 & 3.3 & 3.9 & $<2$ & 1.6 & $<0.1$ \\
\hline $08 \ldots$ & 0.029 & 0.003 & 0.001 & 3.1 & 3.9 & -- & -- & -- \\
\hline \multicolumn{9}{|l|}{ JULY } \\
\hline $13 \ldots$ & 0.017 & 0.005 & $<0.001$ & 2.6 & 3.2 & 17 & 2.2 & $<0.1$ \\
\hline $13 \ldots$ & 0.022 & 0.004 & $<0.001$ & 2.7 & 4.2 & -- & -- & -- \\
\hline $27 \ldots$ & 0.021 & 0.003 & $<0.001$ & 2.1 & 3.2 & 22 & 4.2 & $<0.1$ \\
\hline $27 \ldots$ & 0.045 & 0.002 & $<0.001$ & 2.2 & 3.3 & -- & -- & - \\
\hline \multicolumn{9}{|l|}{ AJjG } \\
\hline $10 \ldots$ & 0.021 & 0.002 & $<0.001$ & $2 \cdot 3$ & 3.2 & $<2$ & 2.7 & $<0.1$ \\
\hline 10 & 0.026 & 0.002 & $<0.001$ & 2.4 & 3.2 & -- & -- & - \\
\hline
\end{tabular}

SITE R2, 400600105154400 LEET HAND VALIEY RESERVOIR NEAR NORTH DAM

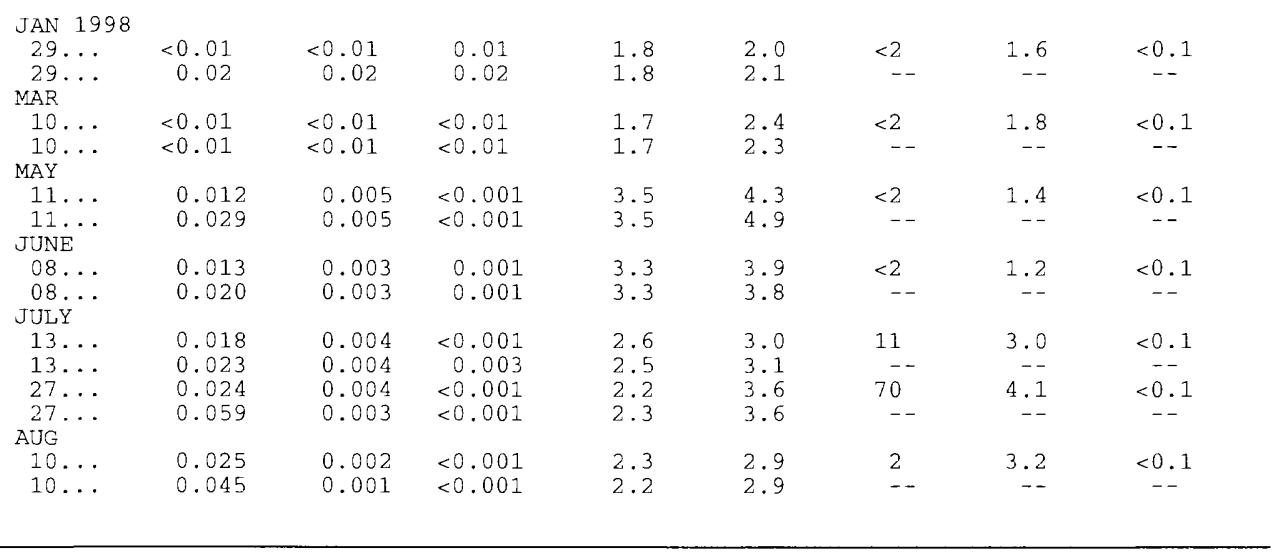


Table 9. Water-quality data for trace elements, Left Hand Valley Reservoir, January-August 1998

[UG/L, micrograms per liter; <, less than]

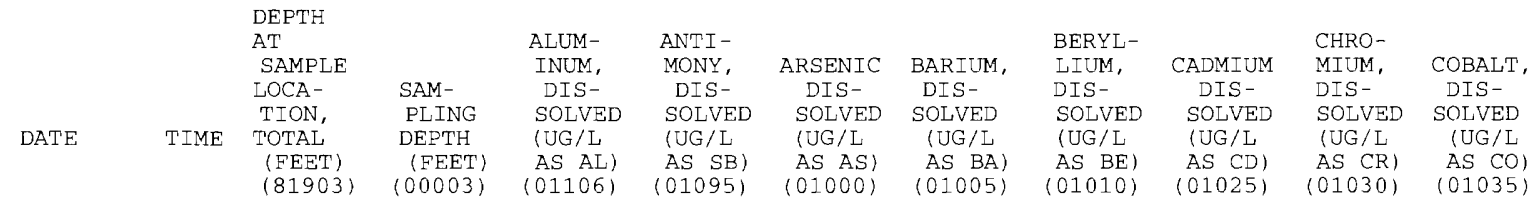

SITE R1, 400546105154900 LEFT HAND VALLEY RESERVOIR NEAR SOUTH DAM

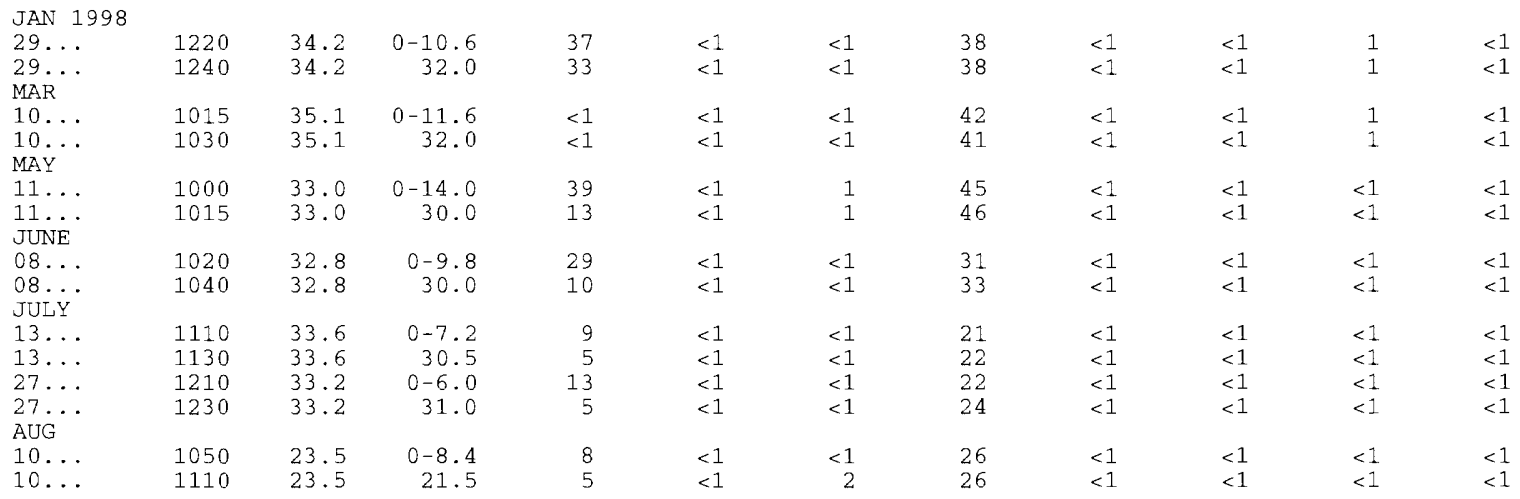

SITE R2, 400600105154400 LEFT HAND VALLEY RESERVOIR NEAR NORTH DAM

\begin{tabular}{|c|c|c|c|c|c|c|c|c|c|c|c|}
\hline $\begin{array}{l}\text { JAN } 1998 \\
29 \ldots\end{array}$ & 1340 & 33.9 & $0-10.0$ & $<1$ & $<1$ & $<1$ & 38 & $<1$ & $<1$ & 1 & $<1$ \\
\hline $29 \ldots$ & 1400 & 33.9 & 32.0 & $<1$ & $<1$ & $<1$ & 41 & $<1$ & $<1$ & 1 & $<1$ \\
\hline $\begin{array}{l}\text { MAR } \\
10 \ldots .\end{array}$ & & & & & & & & & & & \\
\hline $10 \ldots$ & 1115 & 31.2 & $0-11.0$ & $<1$ & $<1$ & $<1$ & 42 & $<1$ & $<1$ & 1 & $<1$ \\
\hline $\begin{array}{l}10 \ldots \\
\text { MAY }\end{array}$ & 1130 & 31.2 & 28.0 & $<1$ & $<1$ & $<1$ & 42 & $<1$ & $<1$ & 1 & $<1$ \\
\hline $\begin{array}{l}\text { MAY } \\
11 \ldots\end{array}$ & & & & & & & & & & & \\
\hline $11 \ldots$ & 1100 & 33.0 & $0-13.0$ & 40 & $<1$ & 1 & 44 & $<1$ & $<1$ & $<1$ & $<1$ \\
\hline $\begin{array}{l}11 \ldots \\
\text { JUNE }\end{array}$ & 1130 & 33.0 & 30.0 & 18 & $<1$ & 1 & 44 & $<1$ & $<1$ & $<1$ & $<1$ \\
\hline $08 \ldots$ & 1130 & 30.5 & $0-10.2$ & 28 & $<1$ & $<1$ & 31 & $<1$ & $<1$ & $<1$ & $<1$ \\
\hline $08 \ldots$ & 1150 & 30.5 & 27.5 & 21 & $<1$ & $<1$ & 29 & $<1$ & $<1$ & $<1$ & $<1$ \\
\hline $13 \ldots$ & 1210 & 31.2 & $0-7.2$ & 10 & $<1$ & $<1$ & 20 & $<1$ & $<1$ & $<1$ & $<1$ \\
\hline $13 \ldots$ & 1230 & 31.2 & 28.5 & 7 & $<1$ & $<1$ & 20 & $<1$ & $<1$ & $<1$ & $<1$ \\
\hline $27 \ldots$ & 1320 & 31.0 & $0-4.2$ & 22 & $<1$ & $<1$ & 21 & $<1$ & $<1$ & $<1$ & $<1$ \\
\hline 27 . & 1330 & 31.0 & 29.0 & 15 & $<1$ & $<1$ & 24 & $<1$ & $<1$ & $<1$ & $<1$ \\
\hline $\begin{array}{l}\text { AUUG } \\
10 . \ldots\end{array}$ & & & $0-80$ & 10 & $<1$ & $<1$ & 28 & $<1$ & $<1$ & $<1$ & \\
\hline & 1210 & 21.5 & 19.5 & 4 & $<1$ & 1 & 28 & $<1$ & $<1$ & $<1$ & $<$ \\
\hline
\end{tabular}


Table 9. Water-quality data for trace elements, Left Hand Valley Reservoir, January-August 1998-Continued

[UG/L, micrograms per liter; <, less than]

\begin{tabular}{|c|c|c|c|c|c|c|c|c|c|c|}
\hline & $\begin{array}{l}\text { COPPER, } \\
\text { DIS- } \\
\text { SOLVED } \\
\text { (UG/L } \\
\text { AS CU) } \\
\text { (01040) }\end{array}$ & $\begin{array}{l}\text { IRON, } \\
\text { DIS- } \\
\text { SOLVED } \\
\text { (UG/L } \\
\text { AS FE) } \\
(01046)\end{array}$ & $\begin{array}{l}\text { LEAD, } \\
\text { DIS- } \\
\text { SOLVED } \\
\text { (UG/L } \\
\text { AS PB) } \\
(01049)\end{array}$ & $\begin{array}{l}\text { MANGA- } \\
\text { NESE, } \\
\text { DIS- } \\
\text { SOLVED } \\
\text { (UG/L } \\
\text { AS MN) } \\
(01056)\end{array}$ & $\begin{array}{c}\text { MOLYB- } \\
\text { DENUM, } \\
\text { DIS- } \\
\text { SOLVED } \\
\text { (UG/L } \\
\text { AS MO) } \\
(01060)\end{array}$ & $\begin{array}{l}\text { NICKEL, } \\
\text { DIS- } \\
\text { SOLVED } \\
\text { (UG/L } \\
\text { AS NI) } \\
\text { (01065) }\end{array}$ & $\begin{array}{l}\text { SELE- } \\
\text { NIUM, } \\
\text { DIS- } \\
\text { SOLVED } \\
\text { (UG/L } \\
\text { AS SE) } \\
(01145)\end{array}$ & $\begin{array}{c}\text { SILVER, } \\
\text { DIS- } \\
\text { SOLVED } \\
\text { (UG/L } \\
\text { AS AG) } \\
\text { (01075) }\end{array}$ & $\begin{array}{c}\text { URANIUM } \\
\text { NATURAL } \\
\text { DIS- } \\
\text { SOLVED } \\
\text { (UG/L } \\
\text { AS U) } \\
(22703)\end{array}$ & $\begin{array}{c}\text { ZINC, } \\
\text { DIS- } \\
\text { SOLVED } \\
\text { (UG/L } \\
\text { AS ZN) } \\
(01090)\end{array}$ \\
\hline
\end{tabular}

SITE R1, 400546105154900 LEFT HAND VALLEY RESERVOIR NEAR SOUTH DAM

\begin{tabular}{|c|c|c|c|c|c|c|c|c|c|c|}
\hline \multicolumn{11}{|c|}{ JAN 1998} \\
\hline $29 \ldots$ & 2 & 20 & $<1$ & 2 & 1 & $<1$ & $<1$ & $<1$ & 2 & $<\frac{1}{2}$ \\
\hline$\underset{\text { MAR }}{29} \ldots$ & 2 & 18 & $<1$ & 2 & 1 & $<1$ & $<1$ & $<1$ & 2 & 2 \\
\hline \multicolumn{11}{|l|}{ MAR } \\
\hline $10 \ldots$ & 1 & $<10$ & $\begin{array}{l}<1 \\
<1\end{array}$ & $\frac{2}{2}$ & $\frac{1}{1}$ & $\begin{array}{l}<1 \\
<1\end{array}$ & $\begin{array}{l}<1 \\
<1\end{array}$ & $\begin{array}{l}<1 \\
<1\end{array}$ & $\frac{2}{2}$ & $<1$ \\
\hline \multicolumn{11}{|l|}{ MAY } \\
\hline $11 \ldots$ & 3 & $<10$ & $<1$ & 2 & 1 & $<1$ & $<1$ & $<1$ & 4 & 2 \\
\hline $11 \ldots$ & 2 & $<10$ & $<1$ & 24 & 1 & $<1$ & $<1$ & $<1$ & 3 & 4 \\
\hline \multicolumn{11}{|l|}{ JUNE } \\
\hline $08 \ldots$ & 3 & $<10$ & $<1$ & $<1$ & $<1$ & $<1$ & $<1$ & $<1$ & 2 & 2 \\
\hline $\begin{array}{l}08 . . \\
\text { JULY }\end{array}$ & 2 & 13 & $<1$ & 101 & 1 & $<1$ & $<1$ & $<1$ & 2 & 4 \\
\hline \multicolumn{11}{|l|}{ JULY } \\
\hline $13 \ldots$ & 2 & $<10$ & $<1$ & $<1$ & $<1$ & $<1$ & $<1$ & $<1$ & $<1$ & 1 \\
\hline $13 \ldots$ & 2 & 13 & $<1$ & 30 & $<1$ & $<1$ & $<1$ & $<1$ & $<1$ & \\
\hline $\begin{array}{l}27 . \\
27 .\end{array}$ & 2 & $<10$ & $<1$ & $<1$ & $<1$ & $<1$ & $<1$ & $<1$ & $<1$ & \\
\hline 27. & 2 & 13 & $<1$ & 110 & 1 & $<1$ & $<1$ & $<1$ & $<1$ & \\
\hline \multicolumn{11}{|l|}{ AUG } \\
\hline $\begin{array}{l}10 \ldots \\
10 \ldots\end{array}$ & $\begin{array}{r}2 \\
<1\end{array}$ & $\begin{array}{l}<10 \\
<10\end{array}$ & $\begin{array}{l}<1 \\
<1\end{array}$ & $\begin{array}{r}<1 \\
478\end{array}$ & 1 & $<1$ & $<1$ & $<1$ & $<1$ & \\
\hline
\end{tabular}

SITE R2, 400600105154400 LEFT HAND VALLEY RESERVOIR NEAR NORTH DAM

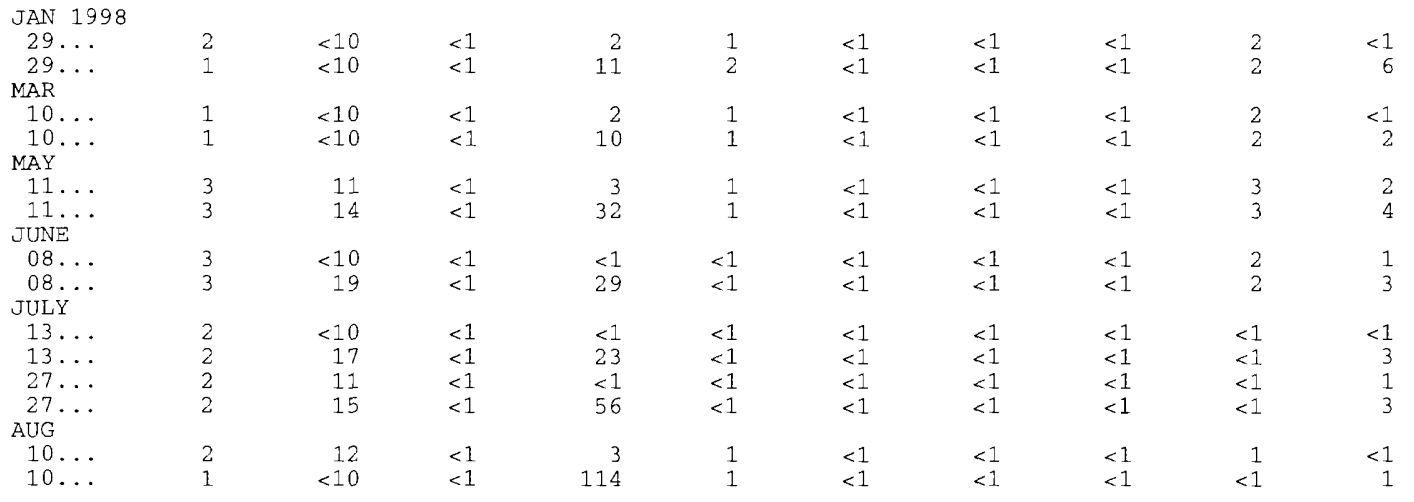


Table 10. Water-quality data for volatile organic compounds and n-nitrosodimethylamine, Left Hand Valley Reservoir, Jar'dary and July 1998

[UG/L, microgram per liter; UNFLTRD, unfiltered; REC, recoverable; <, less than]

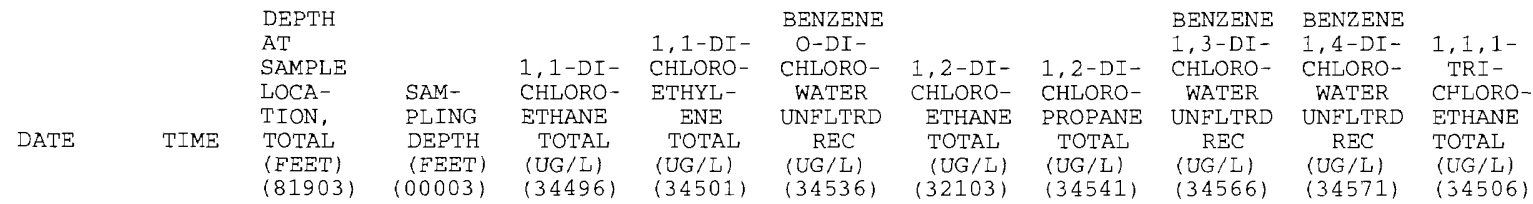

SITE R3, 400551105155700 LEFT HAND VALLEY RESERVOIR NEAR SOUTHWEST INLET

\begin{tabular}{|c|c|c|c|c|c|c|c|c|c|c|c|}
\hline $29 \ldots$ & 1130 & 5.0 & 4.0 & $<0.2$ & $<0.2$ & $<0.2$ & $<0.2$ & $<0.2$ & $<0.2$ & $<0.2$ & $<0.2$ \\
\hline & 130 & 4.0 & 3.0 & $<0.2$ & $<0.2$ & $<0.2$ & $<0.2$ & $<0.2$ & $<0.2$ & $<0.2$ & \\
\hline
\end{tabular}

SITE R4, 400609105154800 LEFT HAND VALLEY RESERVOIR NEAR NORTHEAST INLET

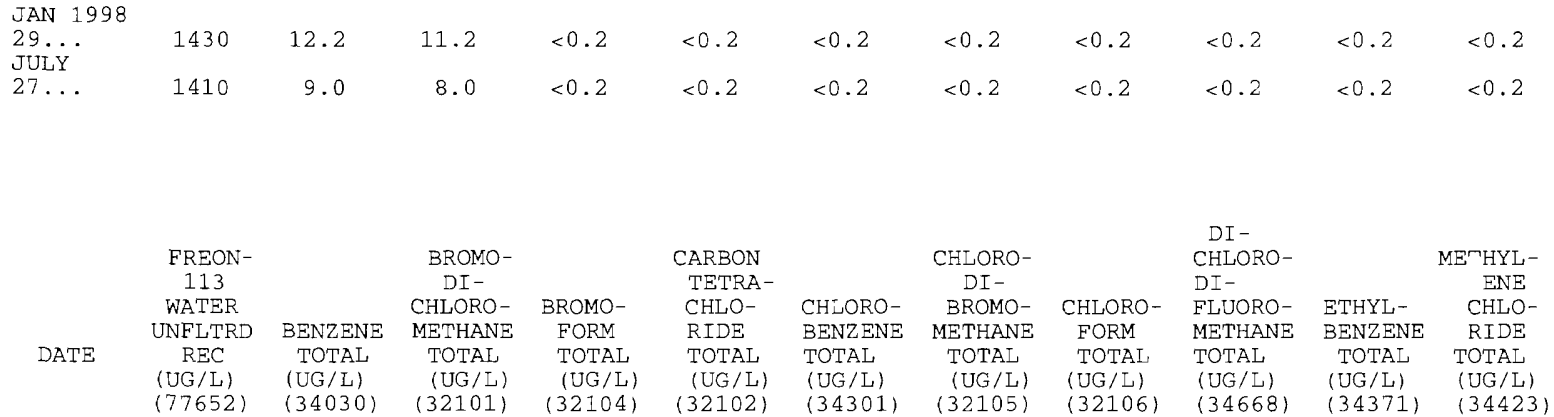

SITE R3,400551105155700 LEFT HAND VALLEY RESERVOIR NEAR SOUTHWEST INLET

\begin{tabular}{|c|c|c|c|c|c|c|c|c|c|c|c|}
\hline $\begin{array}{l}\text { JAN } 1998 \\
29 \ldots \\
\text { JULY }\end{array}$ & $<0.2$ & $<0.2$ & $<0.2$ & $<0.2$ & $<0.2$ & $<0.2$ & $<0.2$ & $<0.2$ & $<0.2$ & $<0.2$ & $<0.2$ \\
\hline $27 \ldots$ & $<0.2$ & $<0.2$ & $<0.2$ & $<0.2$ & $<0.2$ & $<0.2$ & $<0.2$ & $<0.2$ & $<0.2$ & $<0.2$ & $<0.2$ \\
\hline SITE & $R 4,4006$ & 091051548 & 00 LEFT & HAND VALLEY & Y RESERVOI & IR NEAR & NORTHEAST & INLET & & & \\
\hline $\begin{array}{l}\text { JAN } 1998 \\
29 \ldots \\
\text { JULY }\end{array}$ & $<0.2$ & $<0.2$ & $<0.2$ & $<0.2$ & $<0.2$ & $<0.2$ & $<0.2$ & $<0.2$ & $<0.2$ & $<0.2$ & $<0.2$ \\
\hline $7 \ldots$ & $<0.2$ & $<0.2$ & $<0.2$ & $<0.2$ & $<0.2$ & $<0.2$ & $<0.2$ & $<0.2$ & $<0.2$ & $<0.2$ & $<0.2$ \\
\hline DATE & $\begin{array}{l}\text { STYRENE } \\
\text { TOTAL } \\
\text { (UG/L) } \\
\text { (77128) }\end{array}$ & $\begin{array}{l}\text { TETRA- } \\
\text { CHLORO- } \\
\text { ETHYL- } \\
\text { ENE } \\
\text { TOTAL } \\
\text { (UG/L) } \\
(34475)\end{array}$ & $\begin{array}{l}\text { TOLUENE } \\
\text { TOTAL } \\
\text { (UG/L) } \\
\text { (34010) }\end{array}$ & $\begin{array}{c}\text { TRI- } \\
\text { CHLORO- } \\
\text { ETHYL- } \\
\text { ENE } \\
\text { TOTAL } \\
\text { (UG/L) } \\
(39180)\end{array}$ & $\begin{array}{l}\text { TRI- } \\
\text { CHLORO- } \\
\text { FLUORO- } \\
\text { METHANE } \\
\text { TOTAL } \\
\text { (UG/L) } \\
(34488)\end{array}$ & $\begin{array}{l}\text { VINYL } \\
\text { CHLO- } \\
\text { RIDE } \\
\text { TOTAL } \\
\text { (UG/L) } \\
\text { (39175) }\end{array}$ & $\begin{array}{c}\text { XYLENE } \\
\text { WATER } \\
\text { UNFLTRD } \\
\text { REC } \\
\text { (UG/L) } \\
\text { (81551) }\end{array}$ & $\begin{array}{l}\text { CIS-1, } 2 \\
\text {-DI- } \\
\text { CHLORO- } \\
\text { ETHENE } \\
\text { WATER } \\
\text { TOTAL } \\
\text { (UG/L) } \\
\text { (77093) }\end{array}$ & $\begin{array}{c}\text { METHYL } \\
\text { TERT- } \\
\text { BUTYL } \\
\text { ETHER } \\
\text { WATER } \\
\text { REC } \\
\text { (UG/L) } \\
(78032)\end{array}$ & $\begin{array}{c}\text { TRANS- } \\
1,2-D I- \\
\text { CHLORO- } \\
\text { ETHENE } \\
\text { TOTAL } \\
\text { (UG/L) } \\
(34546)\end{array}$ & $\begin{array}{c}\text { N-NITRO } \\
\text { - SODI- } \\
\text { M ITHYL- } \\
\text { AMINE } \\
\text { TOTAL } \\
\text { (UG/L) } \\
(34438)\end{array}$ \\
\hline
\end{tabular}

SITE R3， 400551105155700 LEFT HAND VALLEY RESERVOIR NEAR SOUTHWEST INLET

\begin{tabular}{|c|c|c|c|c|c|c|c|c|c|c|c|}
\hline $\begin{array}{l}\text { UAI ... } \\
\text { JULY }\end{array}$ & $<0.2$ & $<0.2$ & $<0.2$ & $<0.2$ & $<0.2$ & $<0.2$ & $<0.2$ & $<0.2$ & $<0.2$ & $<0.2$ & $<0.6$ \\
\hline 7 & $<0.2$ & $<0.2$ & $<0.2$ & $<0.2$ & $<0.2$ & $<0.2$ & $<0.2$ & $<0.2$ & $<0.2$ & $<0.2$ & $<0.6$ \\
\hline
\end{tabular}

SITE R4,400609105154800 LEFT HAND VALLEY RESERVOIR NEAR NORTHEAST INLET

\begin{tabular}{|c|c|c|c|c|c|c|c|c|c|c|c|}
\hline $\begin{array}{l}29 \ldots \\
\text { JULY }\end{array}$ & $<0.2$ & $<0.2$ & $<0.2$ & $<0.2$ & $<0.2$ & $<0.2$ & $<0.2$ & $<0.2$ & $<0.2$ & $<0.2$ & $<0.6$ \\
\hline $27 \ldots$ & $<0.2$ & $<0.2$ & $<0.2$ & $<0.2$ & $<0.2$ & $<0.2$ & $<0.2$ & $<0.2$ & $<0.2$ & $<0.2$ & $<0.6$ \\
\hline
\end{tabular}


Table 11. Data for selected constituents in bottom sediments at site R2, Left Hand Valley Reservoir, July 27, 198̊

[BOT MAT, bottom material; <63U WS FIELD, wet sieved to less than 63 micrometers in the field; UG/G, microgram per gram, INORG, inorganic; ORG + INORG, organic plus inorganic; <, less than]

\begin{tabular}{|c|c|c|c|c|c|c|c|c|c|c|c|}
\hline $\begin{array}{l}\text { ALUM- } \\
\text { INUM }\end{array}$ & $\begin{array}{l}\text { ANTI- } \\
\text { MONY }\end{array}$ & ARSENIC & BARIUM & $\begin{array}{l}\text { BERYL- } \\
\text { LIUM }\end{array}$ & BISMUTH & CADMIUM & CALCIUM & $\begin{array}{l}\text { CARBON, } \\
\text { INORG, } \\
\text { BOT MAT }\end{array}$ & $\begin{array}{l}\text { CARBON, } \\
\text { ORGANIC } \\
\text { BOT MAT }\end{array}$ & $\begin{array}{c}\text { CARBON, } \\
\text { ORG + } \\
\text { INORG, }\end{array}$ & CERIUM \\
\hline $\begin{array}{l}\text { BOT MAT } \\
<63 \text { U WS } \\
\text { FIELD } \\
\text { PERCENT } \\
(34790)\end{array}$ & $\begin{array}{c}\text { BOT MAT } \\
<63 \text { US WS } \\
\text { FIELD } \\
\text { (UG/G) } \\
(34795)\end{array}$ & $\begin{array}{c}\text { BOT MAT } \\
<63 \mathrm{U} \text { WS } \\
\text { FIELD } \\
(\mathrm{UG} / \mathrm{G}) \\
(34800)\end{array}$ & $\begin{array}{c}\text { BOT MAT } \\
<63 \text { U WS } \\
\text { FIELD } \\
(\text { UG/G) } \\
(34805)\end{array}$ & $\begin{array}{c}\text { BOT MAT } \\
<63 \mathrm{U} \text { WS } \\
\text { FIELD } \\
(\mathrm{UG} / \mathrm{G}) \\
(34810)\end{array}$ & $\begin{array}{c}\text { BOT MAT } \\
<63 \text { UWS } \\
\text { FIELD } \\
(\text { UG/G) } \\
(34816)\end{array}$ & $\begin{array}{c}\text { BOT MAT } \\
<63 \text { W WS } \\
\text { FIELD } \\
(\text { UG /G) } \\
(34825)\end{array}$ & $\begin{array}{c}\text { BOT MAT } \\
<63 \text { U WS } \\
\text { FIELD } \\
\text { PERCENT } \\
(34830)\end{array}$ & $\begin{array}{c}<63 \text { U WS } \\
\text { FIELD } \\
\text { (PER- } \\
\text { CENT) } \\
(49269)\end{array}$ & $\begin{array}{c}<63 U \text { WS } \\
\text { FIELD } \\
\text { (PER- } \\
\text { CENT) } \\
(49266)\end{array}$ & $\begin{array}{c}\text { BOT MAT } \\
<63 \mathrm{U} \text { WS } \\
\text { FIELD } \\
\text { PER_ENT } \\
(49267)\end{array}$ & $\begin{array}{c}\text { BOT MAT } \\
<63 \text { U WS } \\
\text { FIELD } \\
\text { (UG/G) } \\
(34835)\end{array}$ \\
\hline 8.5 & 1 & 11 & 630 & 4 & $<10$ & 1.8 & .83 & .11 & 2.3 & 2.4 & 100 \\
\hline
\end{tabular}

\begin{tabular}{|c|c|c|c|c|c|c|c|c|c|c|c|}
\hline $\begin{array}{l}\text { CHRO- } \\
\text { MIUM }\end{array}$ & $\mathrm{COB}$ & $\mathrm{COF}$ & $\begin{array}{l}\text { EURO- } \\
\text { PIUM }\end{array}$ & & & & & $\begin{array}{l}\text { LANTHA- } \\
\text { NUM }\end{array}$ & $\mathrm{L}$ & & $\begin{array}{l}\text { MAGNE } \\
\text { SIUM }\end{array}$ \\
\hline OT MAT & DT MAT & OT MAT & OT MAT & OTT MAT & OT MAT & BOT MA & BOT M & $A T$ & $\mathrm{~N}$ & MAT & 10 \\
\hline & WS & J WS & $63 \mathrm{U}$ WS & W & J & WS & $<63 \mathrm{UW}$ & $<63$ & 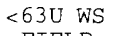 & U & $<63 \mathrm{U} \mathrm{h}$ \\
\hline $\begin{array}{l}\text { FIELD } \\
\text { UG/G) }\end{array}$ & $\begin{array}{l}\text { FIELD } \\
\text { UG /G) }\end{array}$ & $\begin{array}{l}\text { EIELD } \\
\text { UG } / G)\end{array}$ & $\begin{array}{l}\text { FIELD } \\
(\mathrm{UG} / \mathrm{G})\end{array}$ & $\begin{array}{l}\text { FIELD } \\
\text { (UG/G) }\end{array}$ & $\begin{array}{l}\text { FIEID } \\
\text { (UG/G) }\end{array}$ & $\begin{array}{l}\text { FIELD } \\
\text { (UG/G) }\end{array}$ & $\begin{array}{c}\text { FIELD } \\
\text { PERCENT }\end{array}$ & $\begin{array}{l}\text { FIELD } \\
(\mathrm{UG} / \mathrm{G})\end{array}$ & $\begin{aligned} & \text { FI } \\
& \text { (UG }\end{aligned}$ & (UG/G) & $\begin{array}{l}\text { FIELD } \\
\text { PERCENT }\end{array}$ \\
\hline
\end{tabular}

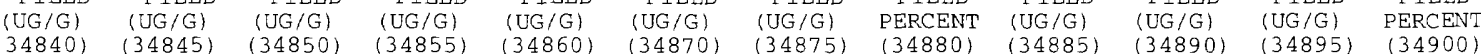

$\begin{array}{lllllllllll}86 & 15 & 100 & <2 & 20 & <8 & <4 & 4.1 & 59 & 120 & 50\end{array}$

\begin{tabular}{|c|c|c|c|c|c|c|c|c|c|c|c|}
\hline $\begin{array}{l}\text { MANGA- } \\
\text { NESE }\end{array}$ & MERCURY & $\begin{array}{l}\text { MOLYB- } \\
\text { DENUM }\end{array}$ & $\begin{array}{l}\text { NEODYM- } \\
\text { IUM }\end{array}$ & NICKEL & NIOBIUI & $\begin{array}{c}\text { PHOS- } \\
\text { PHORUS }\end{array}$ & $\begin{array}{l}\text { POTAS- } \\
\text { SIUM }\end{array}$ & $\begin{array}{l}\text { SCAN- } \\
\text { DIUM }\end{array}$ & $\begin{array}{l}\text { SELE- } \\
\text { NIUM }\end{array}$ & SILVER & ODIUM \\
\hline BOT MAT & BOT MAT & BOT MAT & BOT MAT & BOT MAT & BOT MAT & BOT MAT & BOT MAT & BOT MAT & BOT MAT & BOT MAT & उOT MAT \\
\hline$<63 U$ WS & $<63 \mathrm{U}$ WS & $<63 \mathrm{U}$ WS & $<63 U$ WS & $<63$ U WS & $<63 \mathrm{U}$ WS & $<63$ & $<63 \mathrm{U}$ WS & $<63 \mathrm{U}$ WS & $<63 \mathrm{U}$ & $<63 \mathrm{U}$ WS & $3 U$ WS \\
\hline $\begin{array}{l}\text { FIELD } \\
\text { (UG/G) }\end{array}$ & $\begin{array}{l}\text { FIELD } \\
\text { (UG/G) }\end{array}$ & $\begin{array}{l}\text { EIELD } \\
(U G / G) \\
(34915)\end{array}$ & $\begin{array}{l}\text { FIELD } \\
\text { (UG/G) }\end{array}$ & $\begin{array}{l}\text { FIELD } \\
\text { (UG/G) }\end{array}$ & $\begin{array}{l}\text { FIELD } \\
\text { (UG/G) }\end{array}$ & $\begin{array}{l}\text { FIELD } \\
\text { PERCENT }\end{array}$ & $\begin{array}{l}\text { FIELD } \\
\text { PERCENT }\end{array}$ & $\begin{array}{l}\text { FIELD } \\
\text { (UG/G) }\end{array}$ & $\begin{array}{l}\text { FIEI } \\
\langle\text { UG/C }\end{array}$ & $\begin{array}{l}\text { FIELD } \\
\text { (UG/G) }\end{array}$ & $\begin{array}{l}\text { ELD } \\
\text { CENT }\end{array}$ \\
\hline 349051 & $(34910)$ & (34915) & $(34920)$ & (34925) & (34930) & $(34935)$ & $(34940)$ & $(34945)$ & $(34950)$ & (34955) & 601 \\
\hline
\end{tabular}

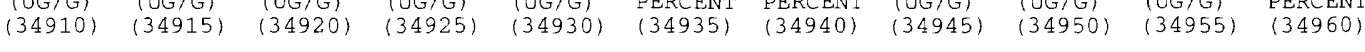

$\begin{array}{llllllllllllll}590 & .12 & 2 & 54 & 39 & 22 & .12 & 2.7 & 15 & 1.2 & .8 & .76\end{array}$

\begin{tabular}{|c|c|c|c|c|c|c|c|c|c|c|}
\hline $\begin{array}{l}\text { STRON- } \\
\text { TIUM }\end{array}$ & SULFUR & $\begin{array}{l}\text { TANTA- } \\
\text { IUM }\end{array}$ & THORIUM & $\begin{array}{l}\text { TITA- } \\
\text { NIUM, }\end{array}$ & TIN & URANIUM & $\begin{array}{l}\text { VANA- } \\
\text { DIUM }\end{array}$ & YTTRIUM & $\begin{array}{l}\text { YTTER- } \\
\text { BIUTM }\end{array}$ & ZINC \\
\hline BOT MAT & BOT MAT & BOT MAT & BOT MAT & BOT MAT & BOT MAT & BOT MAT & BOT MAT & BOT MAT & BOT MAT & BOT MAT \\
\hline$<63 \mathrm{U}$ WS & $<63 \mathrm{U}$ WS & $<63 \mathrm{U}$ WS & $<63 \mathrm{U}$ WS & $<63 \mathrm{U}$ WS & $<63 \mathrm{U}$ WS & $<63 \mathrm{U}$ WS & $<63 \mathrm{U}$ WS & $<63 \mathrm{U}$ WS & $<630$ WS & $<63 \mathrm{U}$ WS \\
\hline EIELD & FIELD & FIELD & FIELD & EIELD & FIELD & FIELD & FIELD & FIELD & FIELD & FIELD \\
\hline (UG/G) & (UG / G) & (UG/G) & $(U G / G)$ & PERCENT & $(\mathrm{UG} / \mathrm{G})$ & (UG/G) & (UG/G) & $(\mathrm{UG} / \mathrm{G})$ & (UG/G) & (UG/G) \\
\hline$(34965)$ & $(34970)$ & $(34975)$ & $(34980)$ & $(492.74)$ & $(34985)$ & $(35000)$ & $(35005)$ & $(35010)$ & $(35015)$ & $(35020)$ \\
\hline 180 & .09 & $<40$ & 21 & .39 & $<5$ & 12 & 170 & 22 & 1 & 370 \\
\hline
\end{tabular}

